\title{
مكانة السلطة التشريعية في ضوء التعديل الدستوري الجزائري لسنة 2016
}

\author{
The Status of the Legislative Power in Light of the Algerian
}

Constitutional Amendment of 2016

تاريخ الاستلام : 2019/031/21؛ تاريخ القبول : 2019/05/23

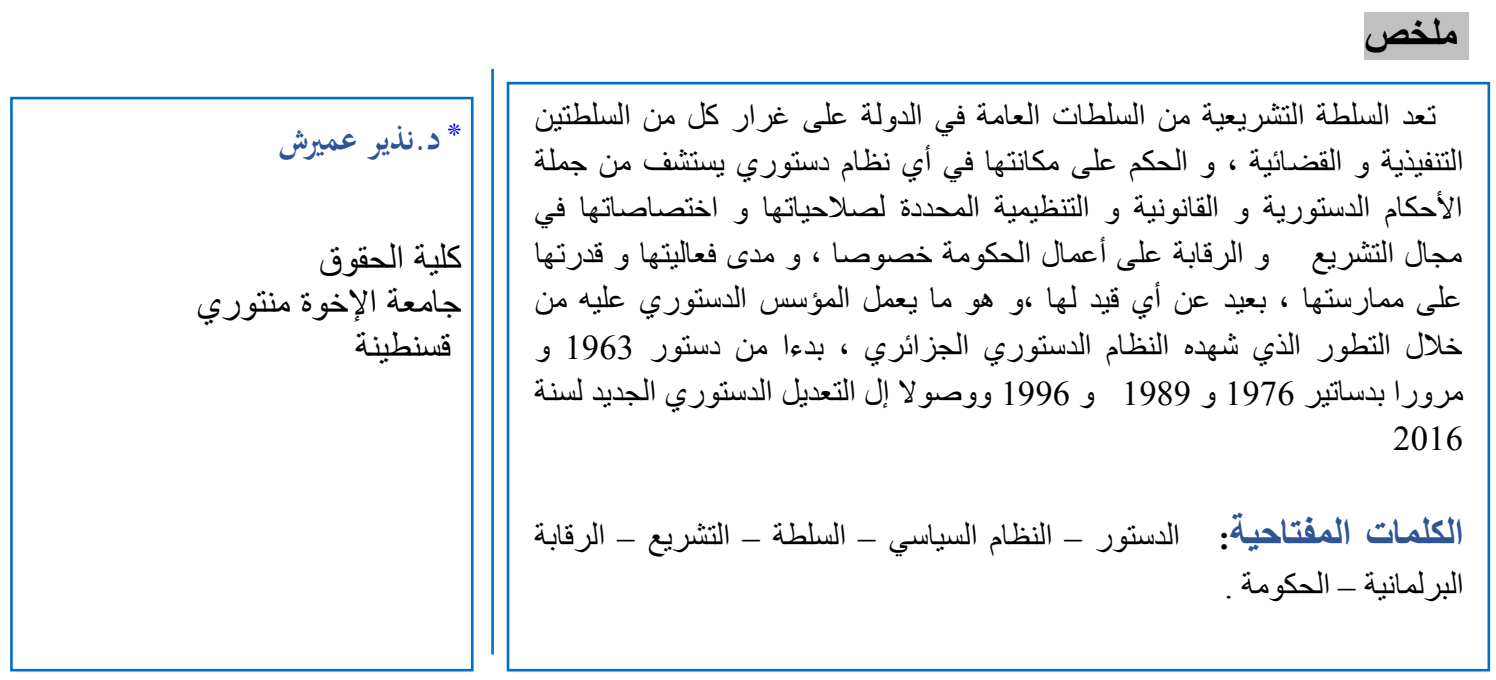

\section{Abstract}

The Legislative power is one of The Public Authorities of the State as well as the executive and judicial authorities. The determination of the Legislative power's status in any constitutional system emerged from constitutional, Legal and regulatory provisions specific for its Powers and competences in field of legislation, oversight of the work of the government in particular, and the extent of its effectiveness and ability to exercise that far from any restriction. The principle who tries the constitutional founder to establish it through the framework that began in 1963, passed through the constitutions of 1976, 1989, 1996 and up to the new constitution of 2016.

Keywords: Constitution - Political system Power - Legislation - Parliamentary oversight Government.

\section{Résumé}

Le pouvoir législatif est considéré parmi les pouvoirs importants dans l'état à l'instar des pouvoirs exécutif et judiciaire. Et le juger sur sa stature dans n'importe quel régime (système) constitutionnel, relève d'un ensemble d'amendements (de dispositions) constitutionnels d'ordre légal et organisationnel définissant ses prérogatives, ainsi que ses spécialités en matière de la législation et le contrôle sur les activités du gouvernement notamment, et à quel point, son efficacité et sa capacité lors de son exercice ; et ce, loin de toute contrainte .Ce dont réside le travail du fondateur constitutionnel, au vue de l'évolution qu'a connue le régime (système) constitutionnel algérien, à partie de de la constitution de 1963, puis celles de 1976, 1989, 1996, jusqu'au nouvel amendement de la constitution de 2016.

Mots clés: Constitution - régime (système) politique - pouvoir - législation - contrôle parlementaire.

* Corresponding author, e-mail: n.amireche2018@ gmail.com

(C) جامعة الاخوة منتوري قسنطينة 1، الجزائر 2019. 


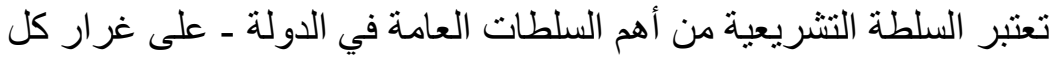

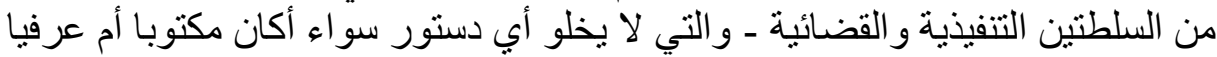

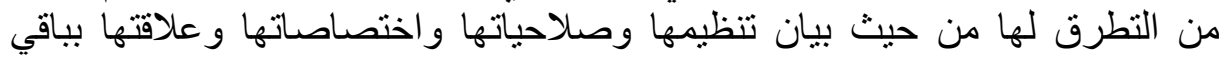

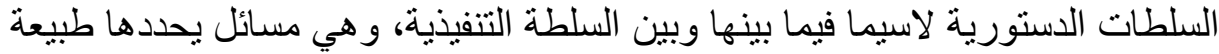

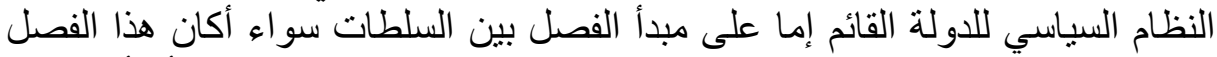

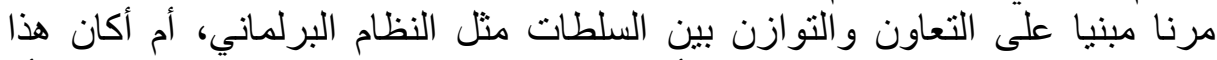

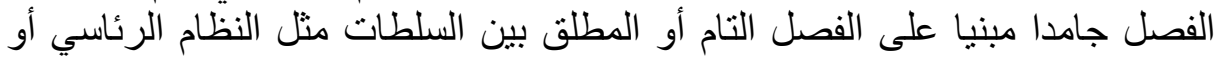

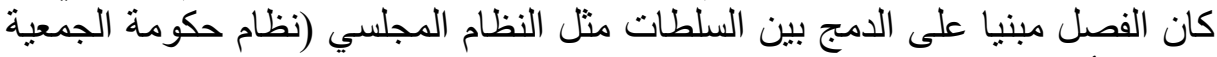
النيابية) أم كان النظام السياسي نظاما شبه رئاسي (مزيج وخليط بين النظامين البرلماني

إن موضوع مكانة السلطة النشريعية في أي نظام سياسي في أي دولة في

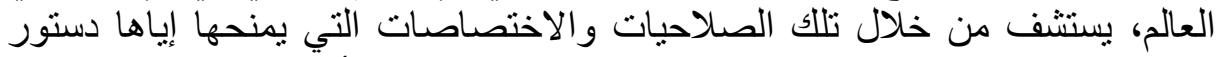

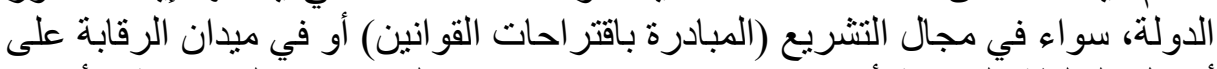

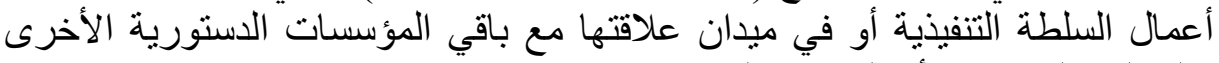

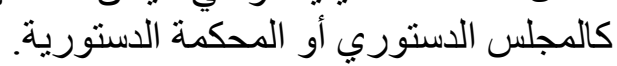

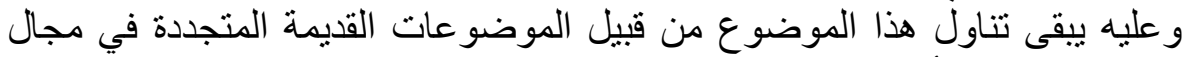

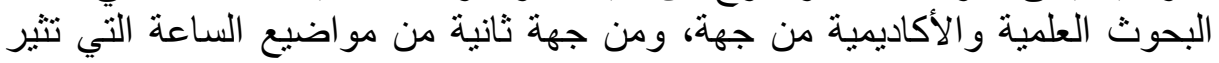

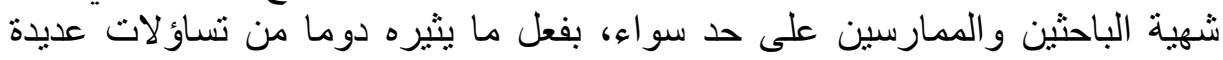

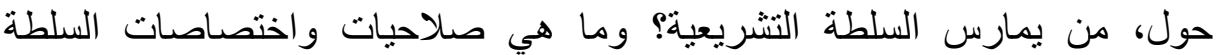
التشريعية؟ وما مدى فعاليتها؟ و لا شك أن الإجابة على كلى كل هذه التساؤلات الفرعية

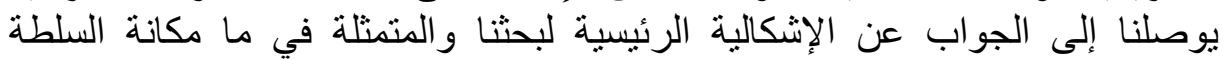

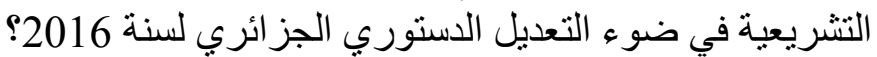

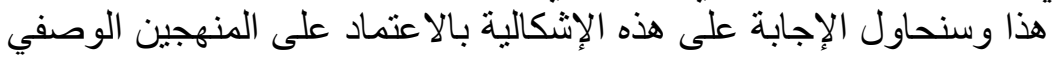

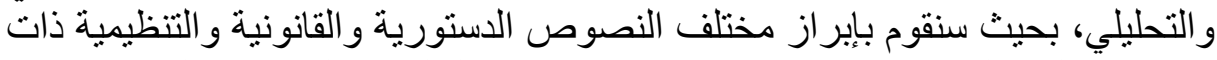

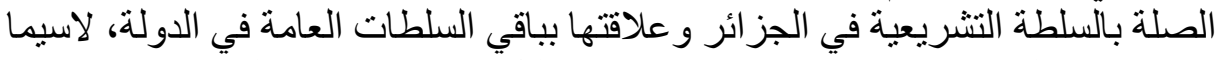

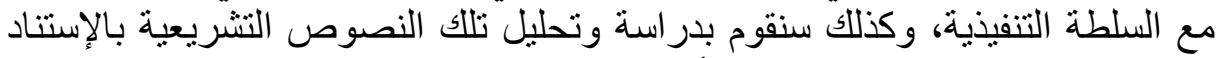

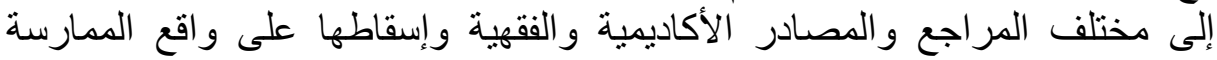
الميدانية وكيفية تعاطي مؤسسات الدولة النئ معها. كما ستكون إجابتنا على الإشكالية الرئيسية و التساؤلات الفيات الفرعية المذكورة

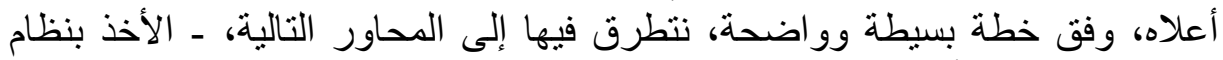

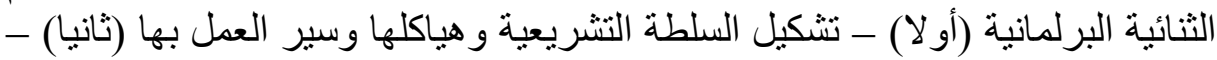
صلاحيات واختصاصات السلطة الأنة التشريعية (ثالثا). أولا: الأخذ بنظام الثنائية المجلسية (نظام الغرفتينين

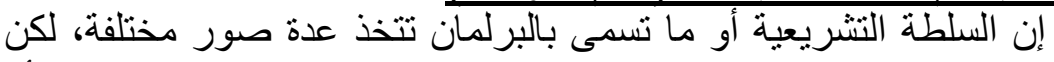

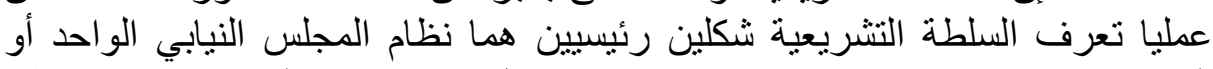

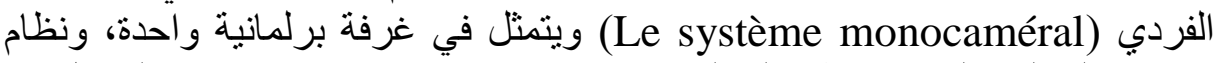
ازدو اج المجلس النيابي "نظام المجلسين" (Le système bicaméral) و المتمنل في

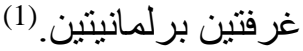
و الجزائر على غرار عديد دول العالم مثل بريطانيا (مهذ نظام الغرفنتين)

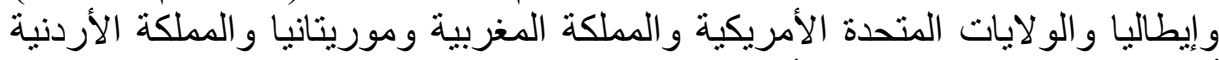

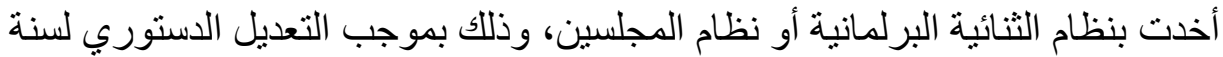
1996، واستمرت في الأخذ به عبر مختلف التعديلات الدستورية اللاحقة (تعديل 
2002، تعديل 2008، تعديل 2016)، بعدما انتهجت خلال الدساتير السابقة نظام

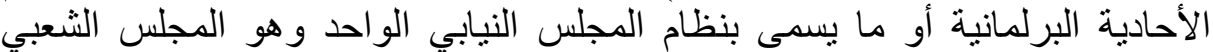

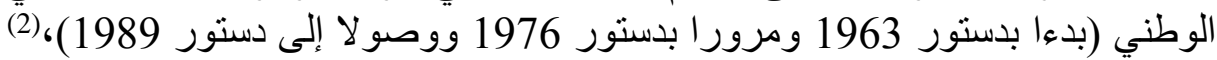
وبالرجوع إلى التعديل الدستوري لسنة 2016، فقد نصت المادة 112 منه على النه أنه

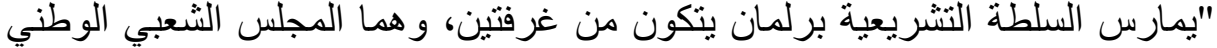

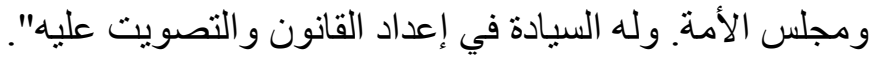
1

قدم الكثير من الباحثين والفقهاء والممارسين عدة أسباب ومبررات أدت إلى إلى

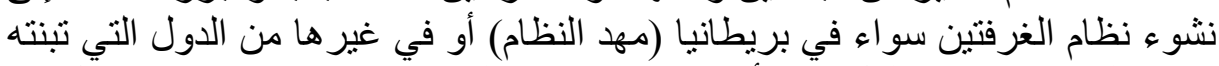

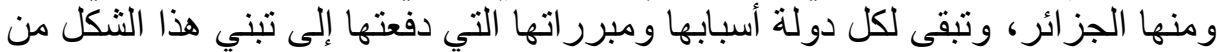

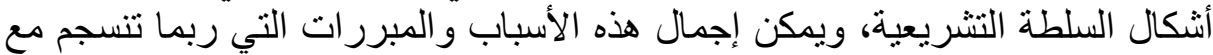

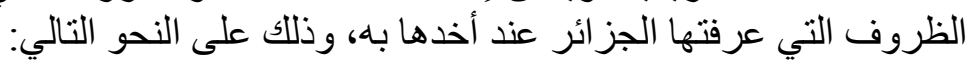
1- وجود غرفة ثانية هو تأكيا للايمقر اطية:

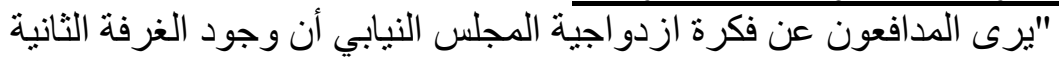

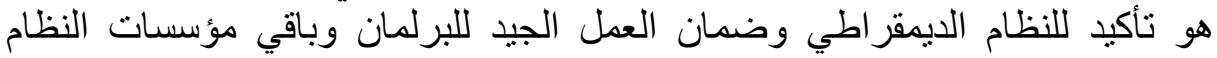

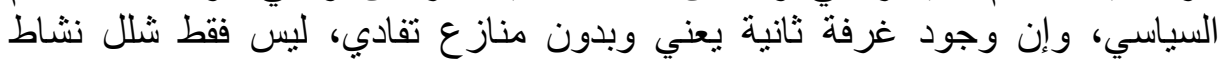
البرلمان بل وكل النظام السياسي للبلاد".

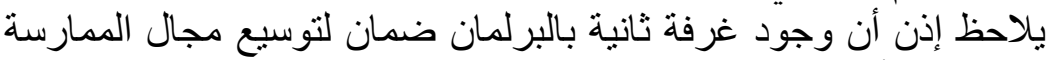

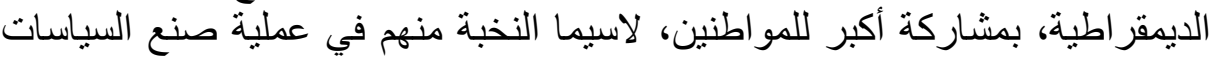

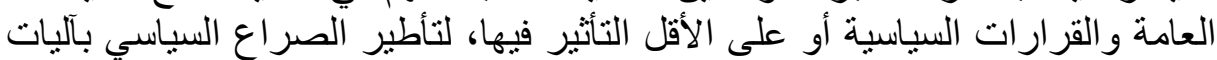

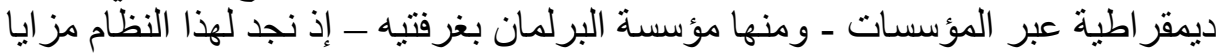

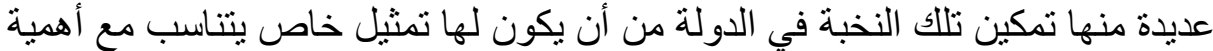

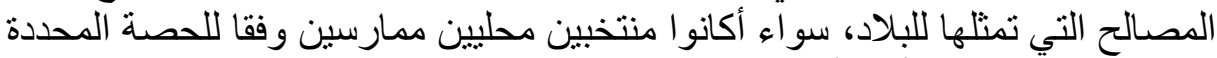

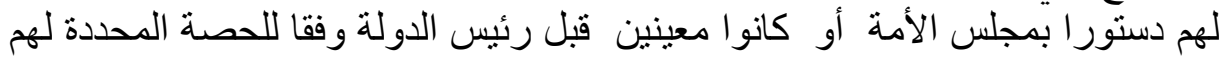

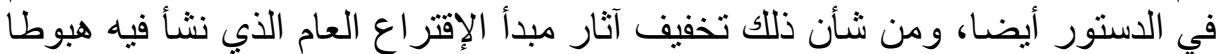

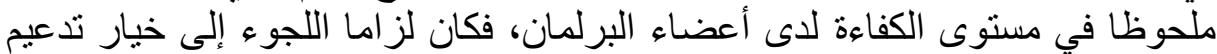

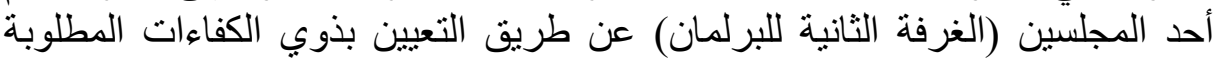

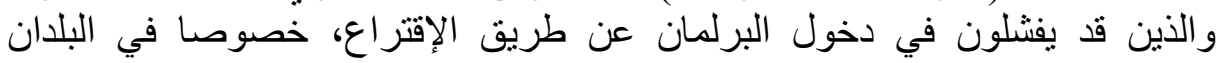

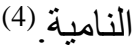

\section{2- وجود غرفة ثانية من شأنه تأكيا توازن وتضامن الأنظمة الايمقراطية:}

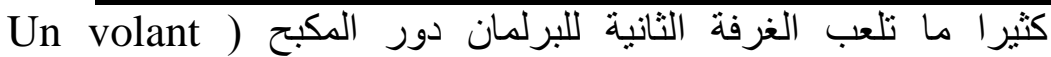

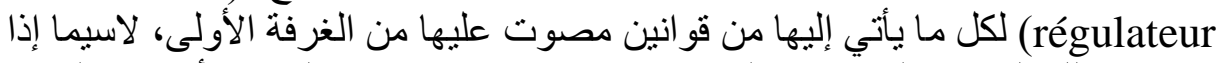

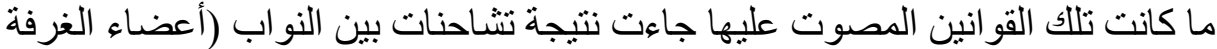

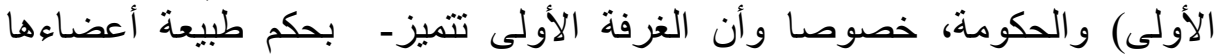

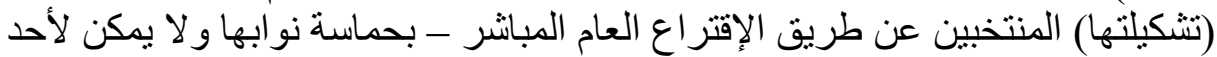

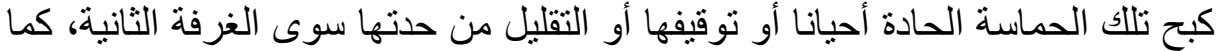

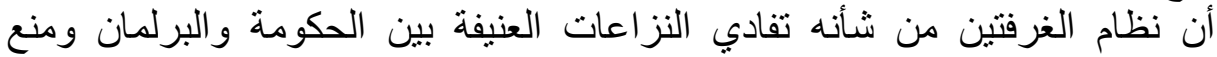

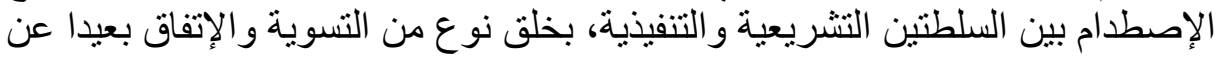

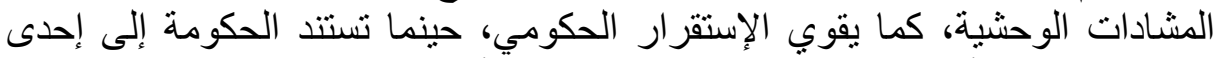
الغرفتين طبقا للأغلبية التي تشكلها من منطلق مبدأ التعاون بين السلطنين التشريعية التئية

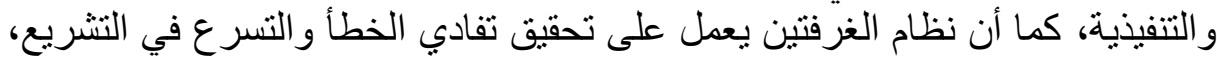

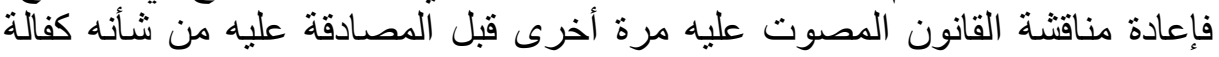

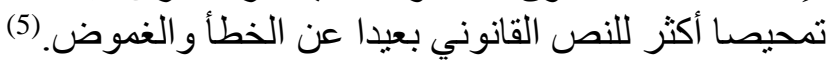


و لا شك أن تأسيس غرفة ثانية في البرلمان الجزائري بموجب التعديل

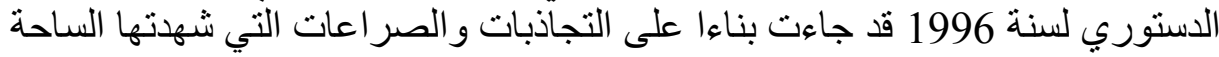

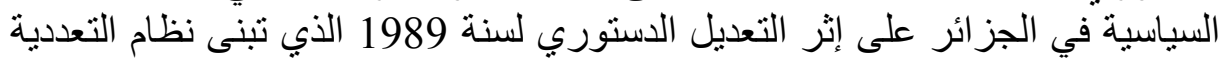

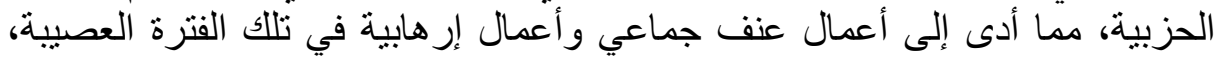

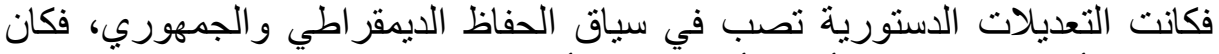

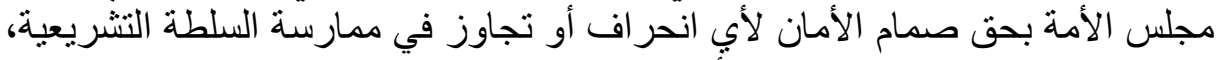

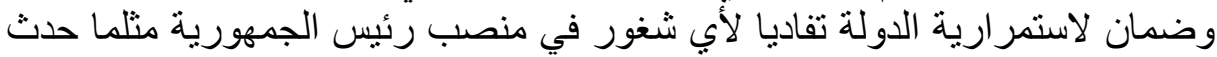

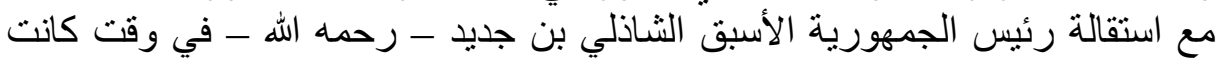

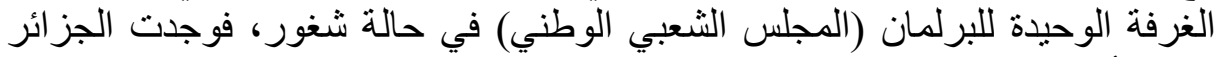

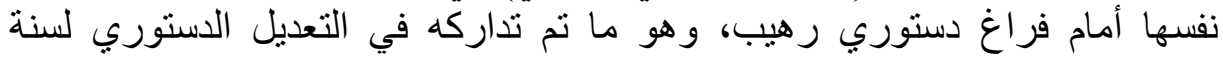

(6). 1996

\section{2) - الاعائم الأساسية لنظام الغرفتين:}

يذهب جانب من الفقه الدستوري إلى القول بأن نظام الغرفتين يقوم على دعامتين أساسيتين هما:

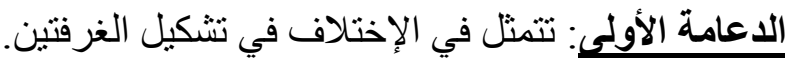

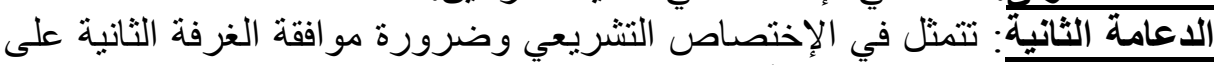

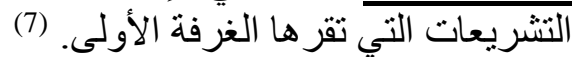
فبالنسبة للاعامة الأولى فهي منطقية بحيث أن الإختلاف في تشكيلة غرفتي

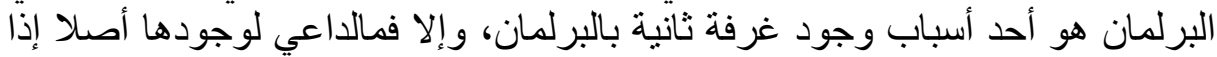

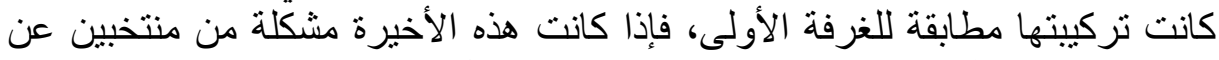

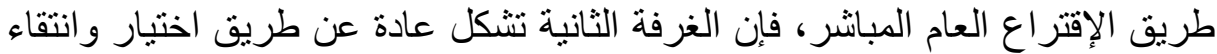

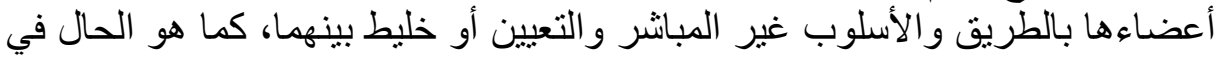

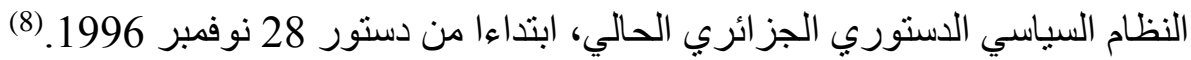

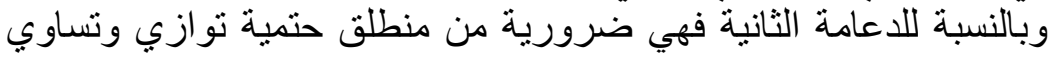

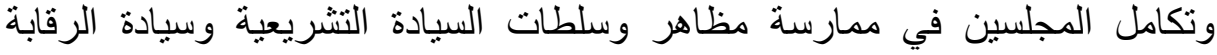
السياسية البرلمانية، بحيث تكون سلطة وسيادة التشريع و الرقابة السياسية البرلية المانية

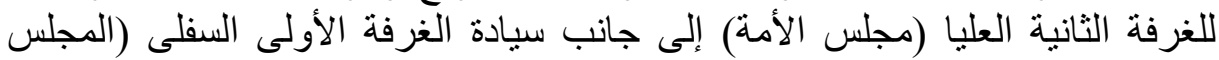
الثعبي الوطني).

\section{تُاتيا: تشكيل السلطة التشريعية وهياكلها وسير العمل بها.}

كما سبق ذكره فان السلطة التشريعية ـ طبقا لنص المادة 112 من الدستور

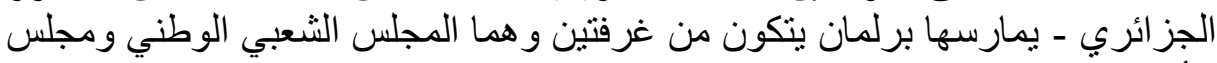

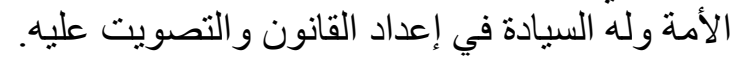
و عليه سنتطرق إلى تشكيل كل غرفة الته على حدة.

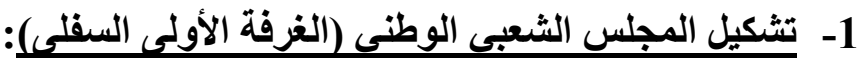

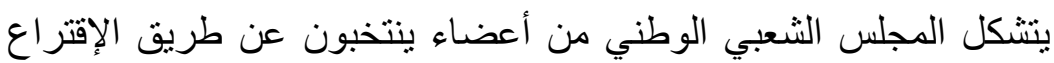

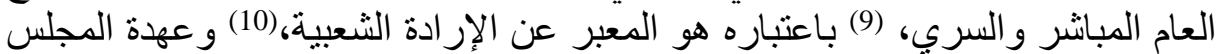

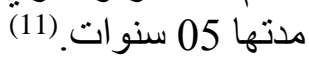

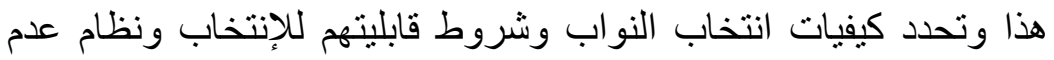

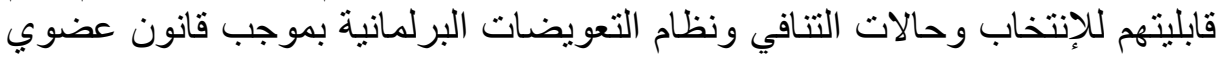

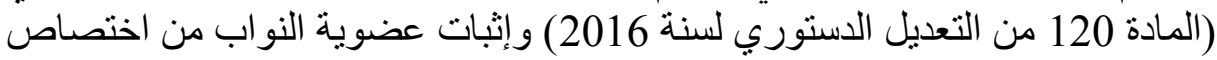


المجلس الشعبي الوطني (المادة 121 من التعديل الدستوري لسنة 2016)، ومهمة ولادئ النائب وطنية، قابلة للتجديد، و لا يمكن الجمع بينهما وبين مهام أو وظائف التهن أخرى (المادة

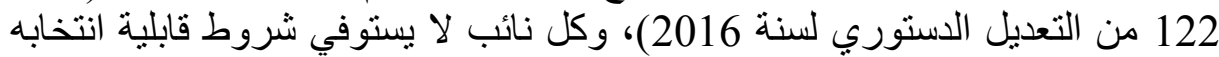

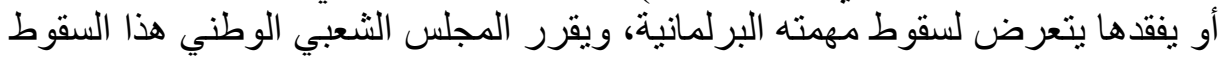
بأغلبية أعضائه (المادة 123 من التعديل الدستوري لسنة 2016).

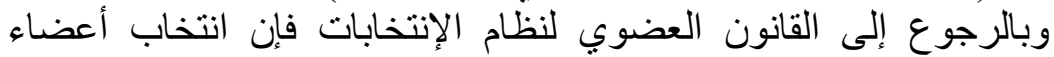

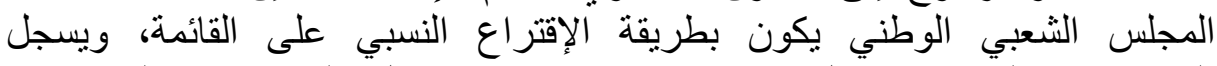
المترشحون بالترتيب في كل دائرة انتخابية في قو ائم تشتئمل على اعلى عدد من المترشحين

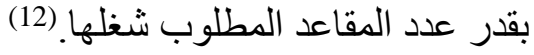

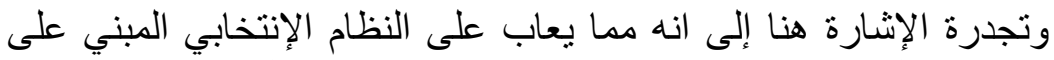

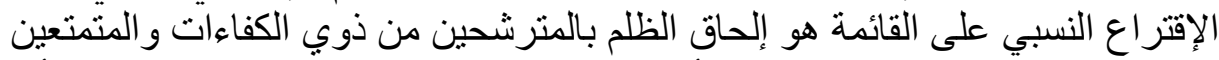

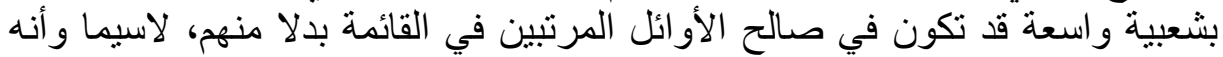

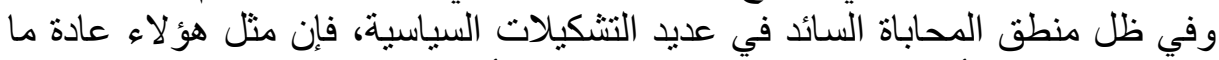

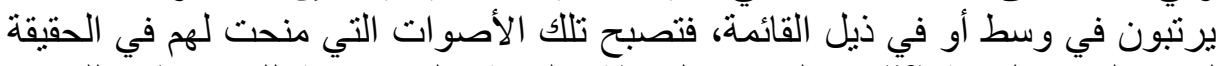

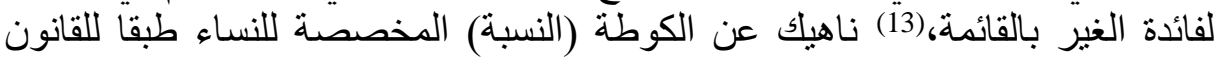

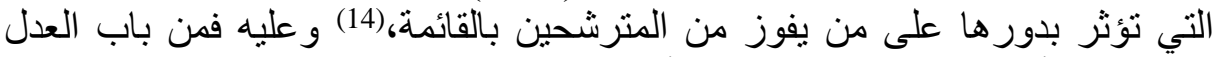

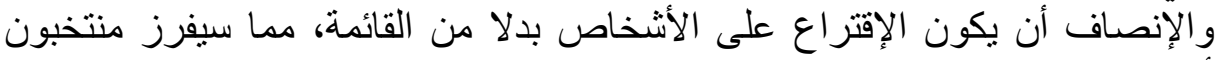

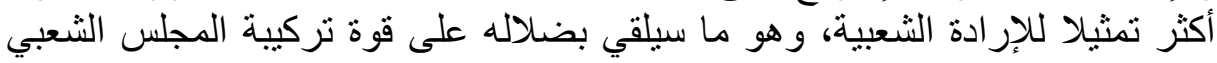

و على ذكر النسبة المفروضة للنساء في كل قائمة ترشيحات سواء أكانت

الوطني.

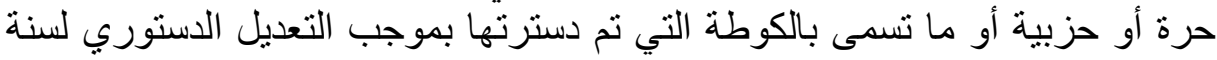

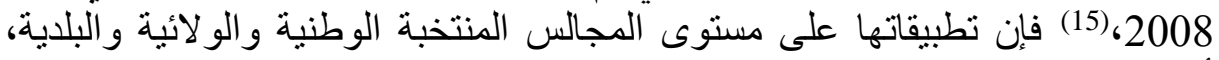

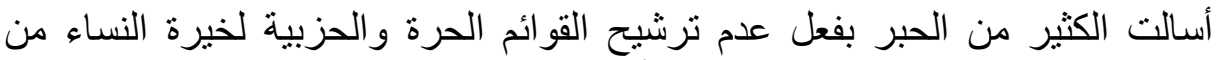

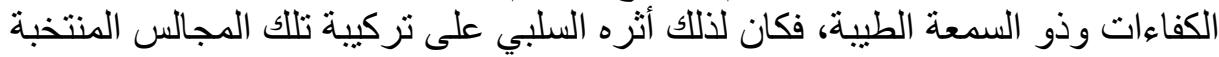

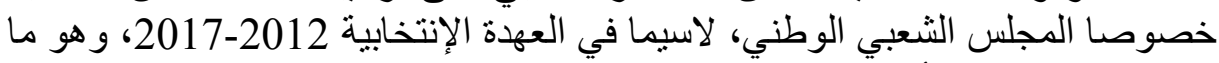

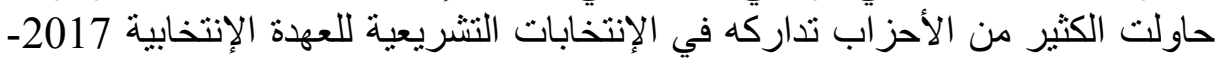

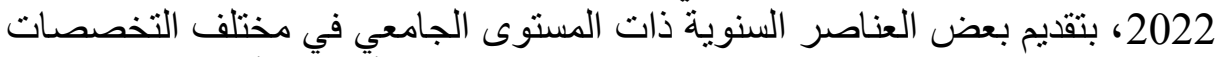

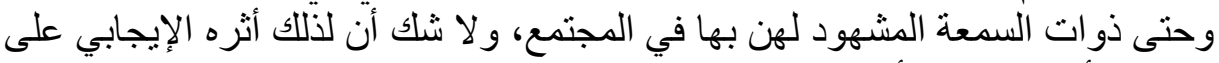

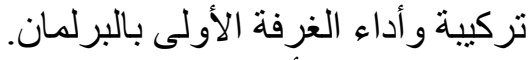

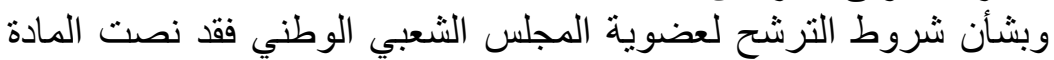
92 من القانون العضوي رقم 16-10 لنظام الإنتخابات على أنه: " يشترط الثي في المترشح إلى المجلس الثعبي الوطني ما يأني: المني:

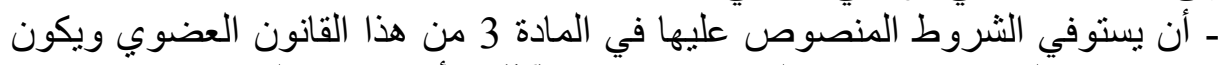

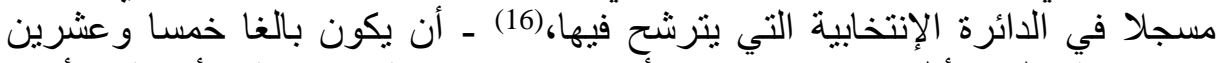

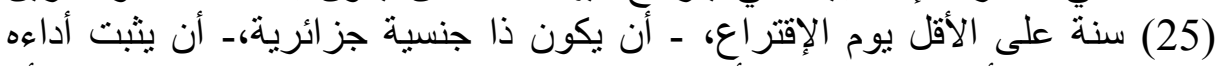

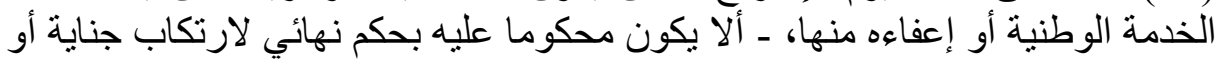

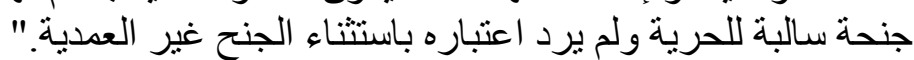

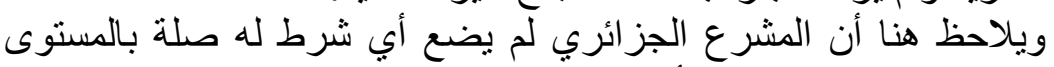

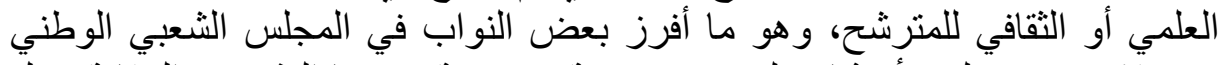

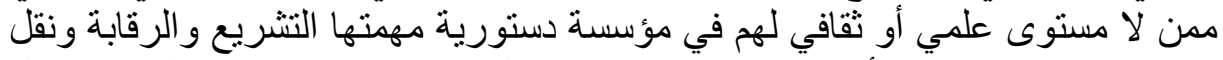

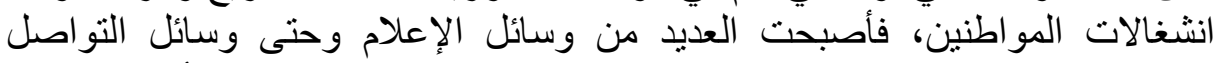

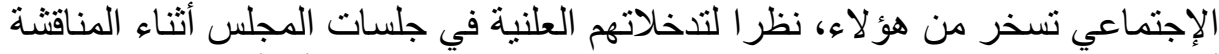

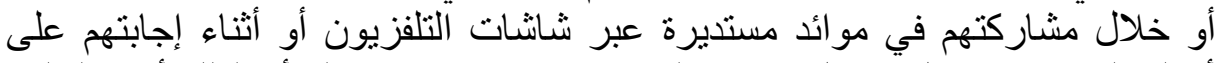

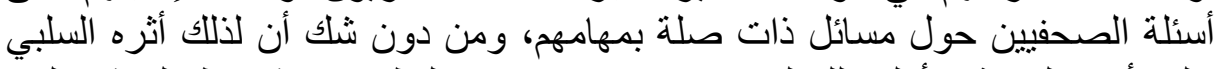

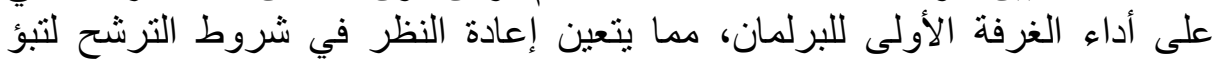


منصب مشرع باسم الثعب وباسم الأمة، بإضافة شرط يتعلق بتوفر حد معين من المستوى العلمي و الثقافي.

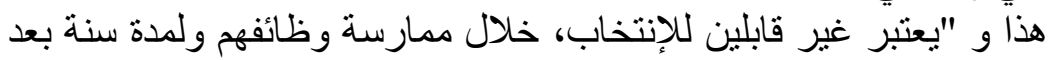

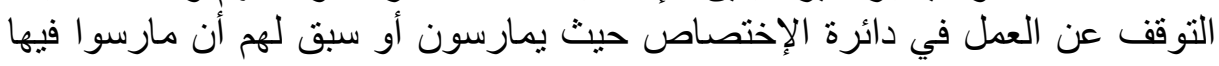

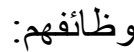

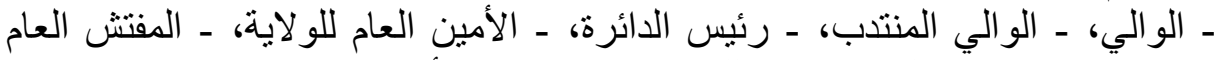

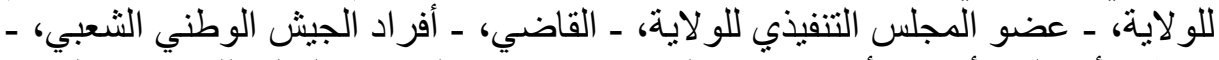

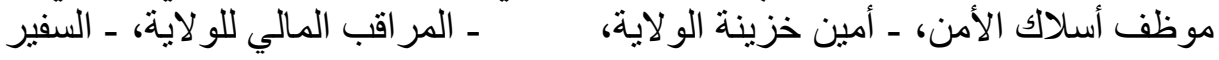

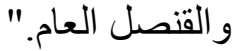

\section{2-تثكيل مجلس الأمة (الغرفة الثانية العليا):}

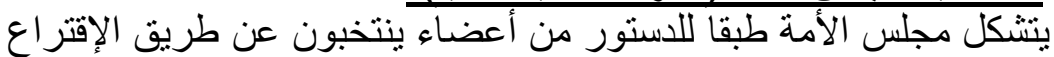

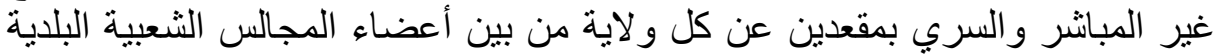

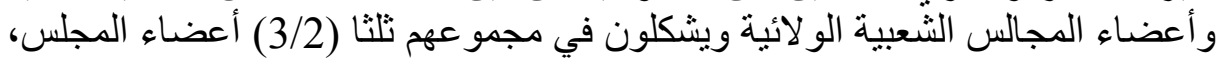

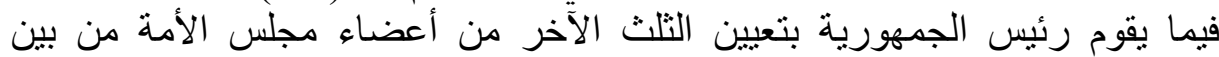

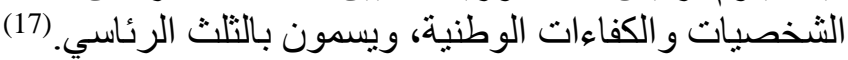

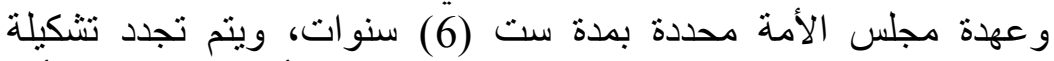

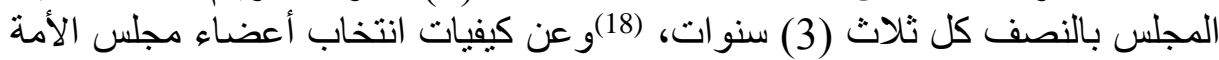

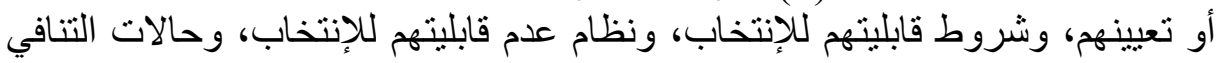

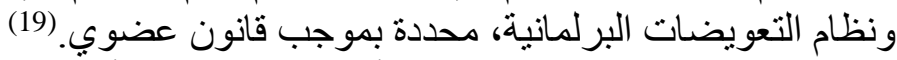

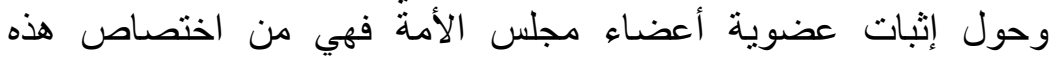

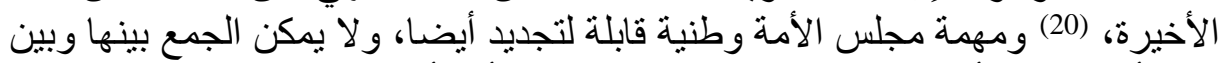

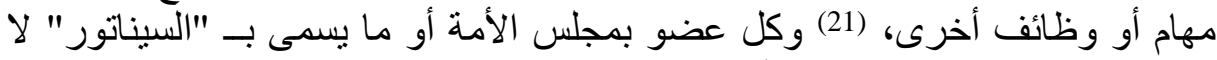
يستوفي شروط قابلية انتخابه أو يفقدها، يتعرض لسقوط مهيته البرلمانية، ويقرر

المجلس هذا السقوط بأغلبية أعضائه. (22)

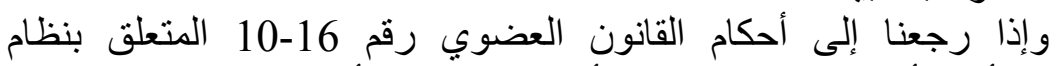
الإنتخابات، فقد أورد أحكاما متعلقة بانتخاب أعضاء مجلس الأمة (المنتخبين)، إذ نصت المتان

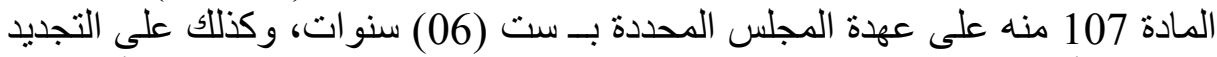

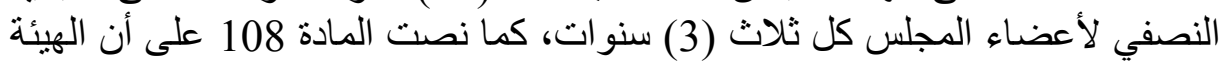

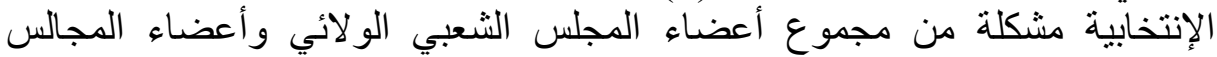

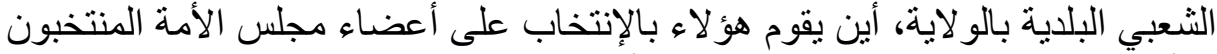

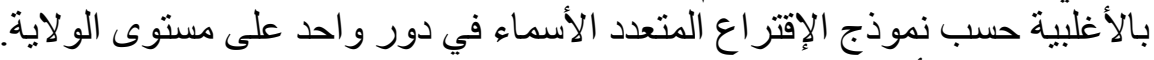

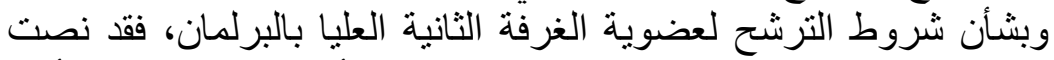

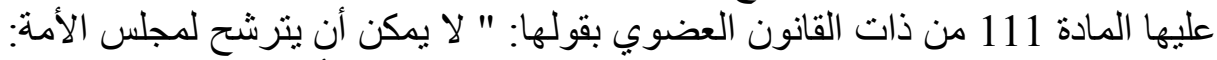

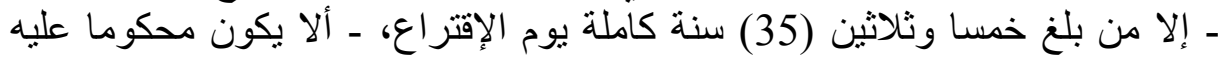

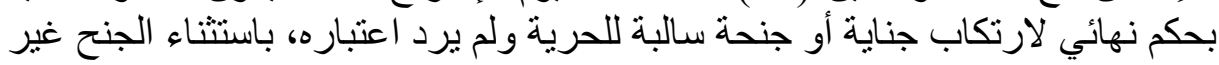

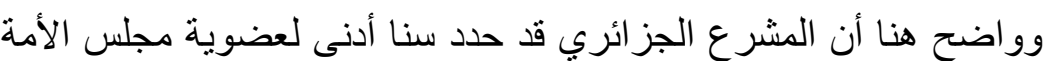

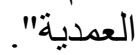

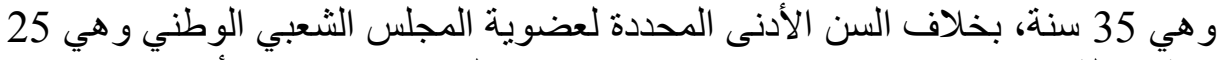

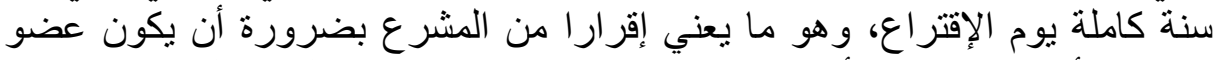

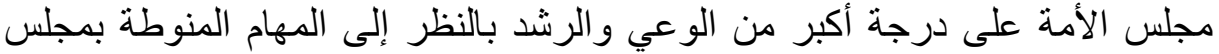

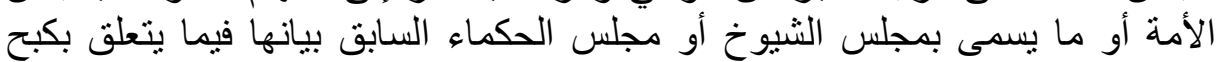
المشاحنات و التلاسنات و المشادات التي قد تثور بين المجلس الثعبي الوطني و الحكومة 
أثناء عملية النقاثات و التصويت على اقتر احات ومشاريع القوانين، فيقوم مجلس الأمة

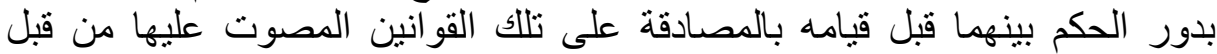
الغرفة السفلى للبرلمان (المجلس الشعبي الوطني)، حفاظا على السير العادي لمؤسسات

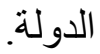

لكن يبقى عدم وضع شروط خاصة بالمستوى العلمي و الثقافي لعضو التوبة

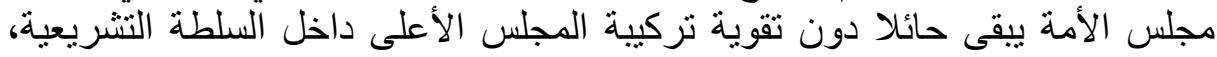

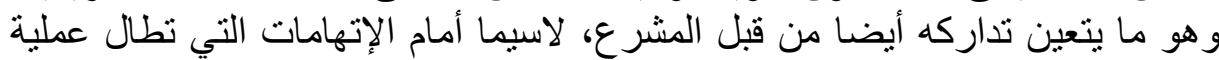

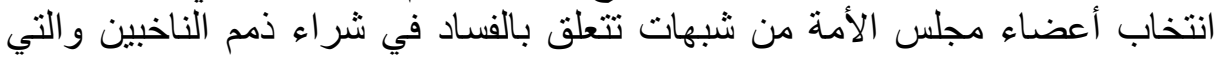

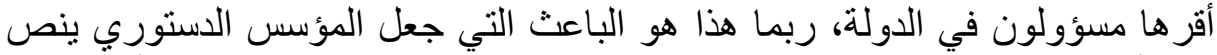

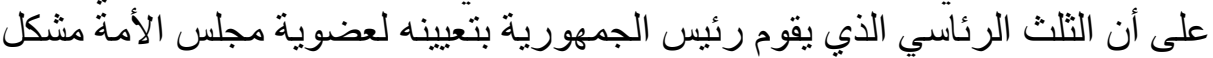

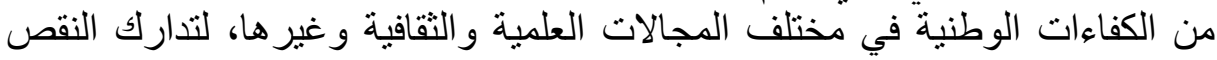
الحاصل في نوعية الثلثنين المنتخبين من فبل المجالس المحلية. 2) -هياكل السلطة التثريعية وسير فئر العمل بها:

بالرجوع إلى أحكام القانون العضوي رقم 16 - 12 الذي بحدي بحد تنظيم

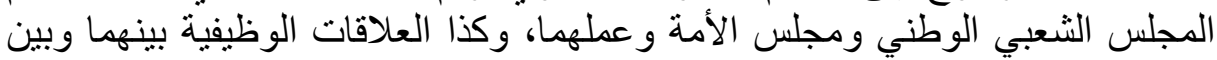

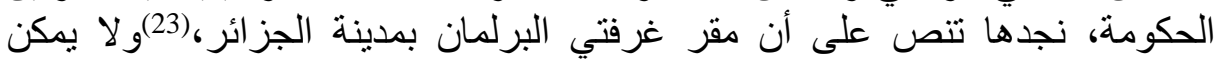

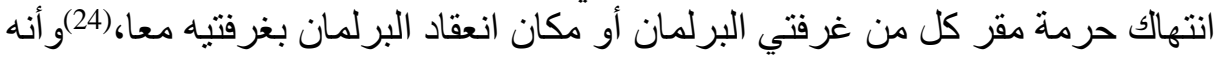

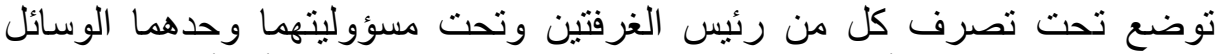

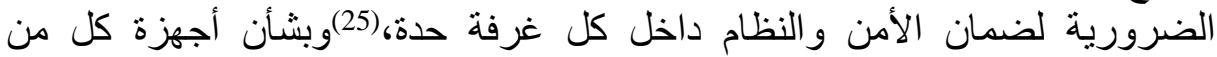

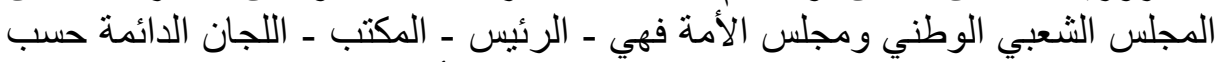

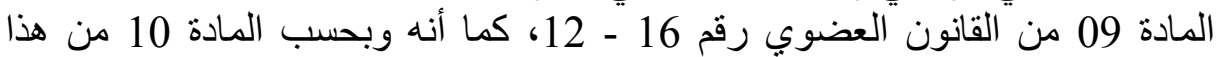
الأخير، فبإمكان كل غرفة أن تنشأ هيئات تتسيقية واستشارية أو رقابية طبقا لأحكام

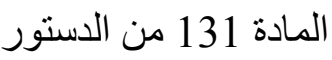

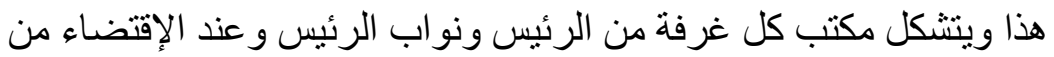

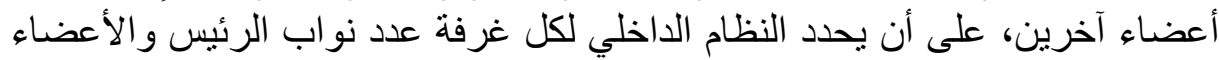

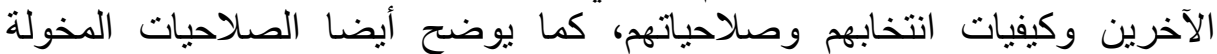

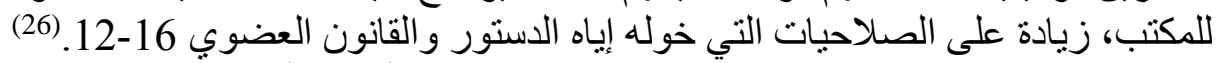

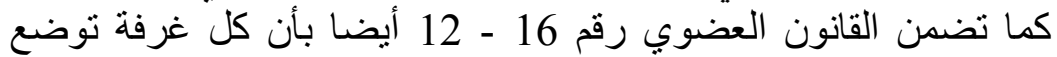

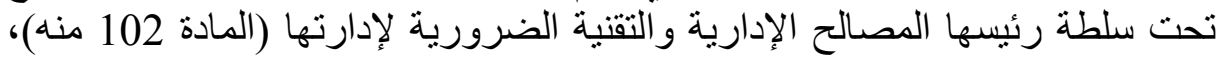

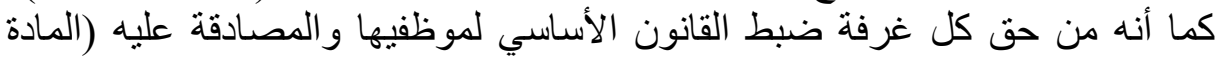

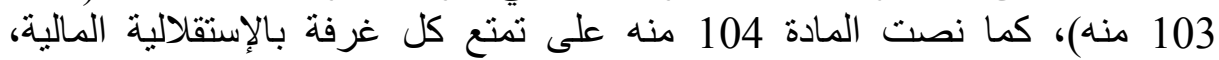

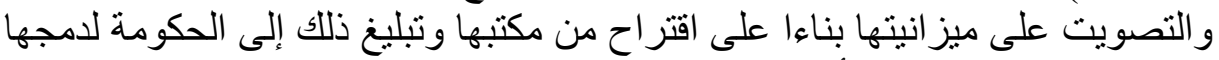

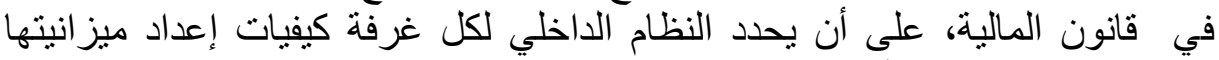

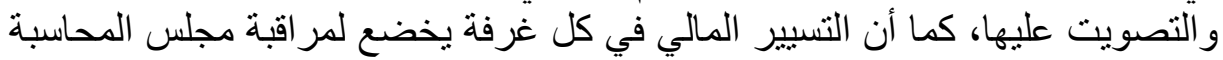
(المادة 105 منه).

وبالرجوع إلى أحكام النظام الداخلي لكل من المجلس الشعبي الوطني

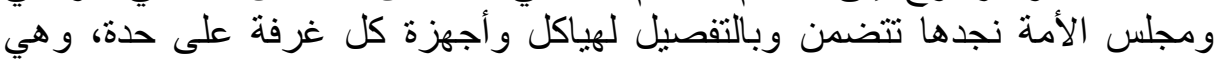

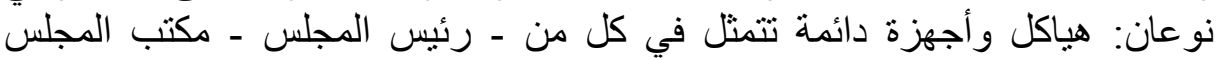

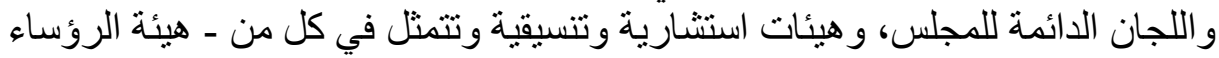
ـ هيئة التنسيق ـ المجمو عات البرلمة ولمانية. 1 - الأجهزة الأئمة: أ- رئيس المجلس: 
فبالنسبة لرئيس مجلس الأمة فقد أصبح بعد إنشاء مجلس الأمة في النظام

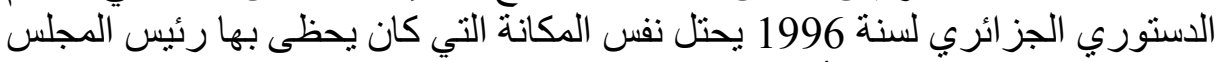

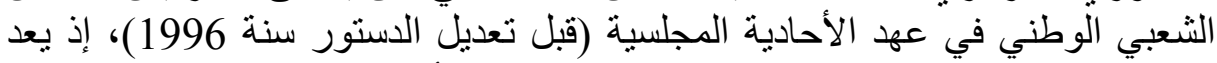

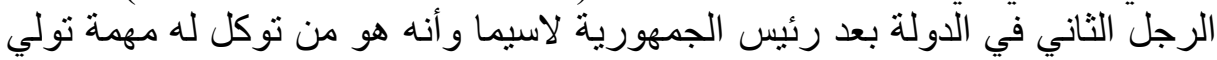

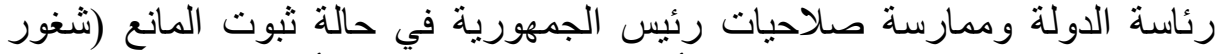

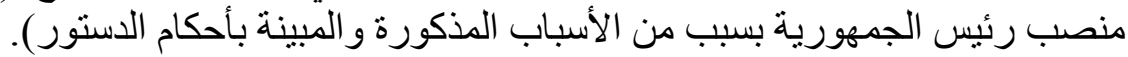

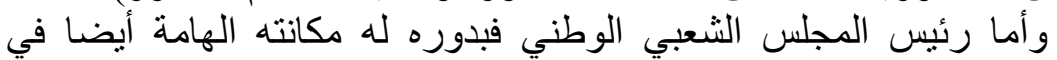

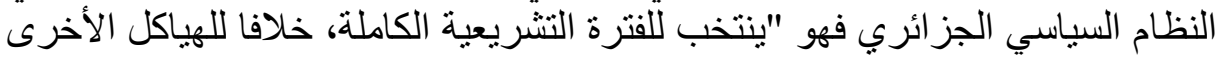

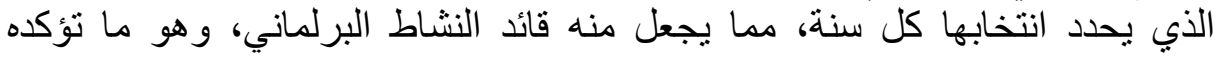

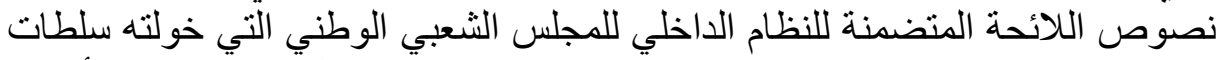

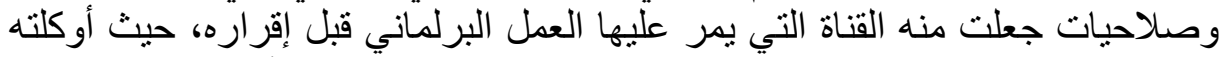

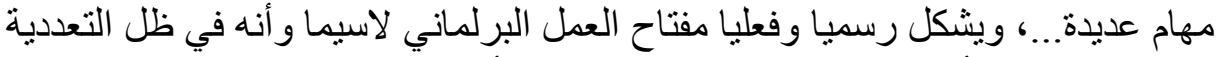

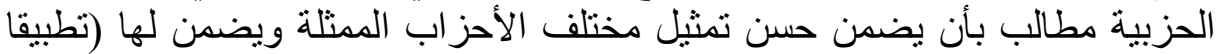

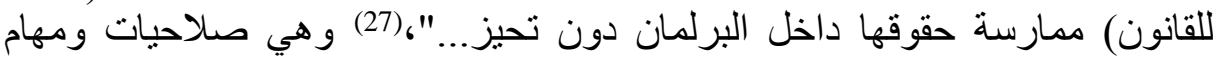

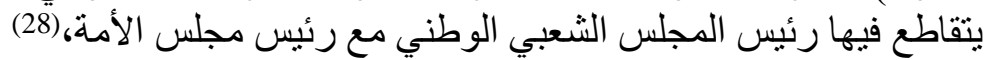

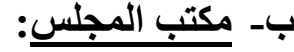

بالنسبة لمكتب المجلس بكل من غرفتي البرلمان، فهو يتكون من رئيس

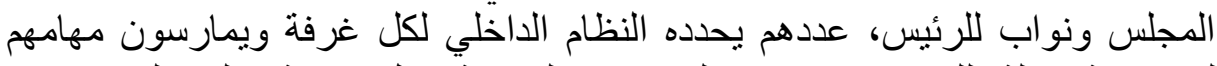

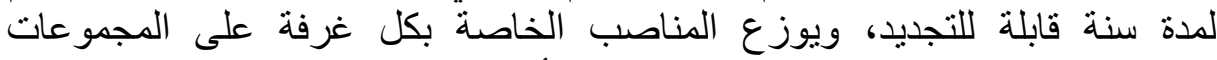
البرلمانية بحسب التمثيل النسبي، وصلاحيات أخرى لمكتب المناصن المجلس محددة بالنظام

\section{ج- اللجان الائمة:} الداخلي لكل غرفة.

بالنسبة للجان الدائمة للمجلس الشعبي الوطني وكذا لمجلس الأمة فهي

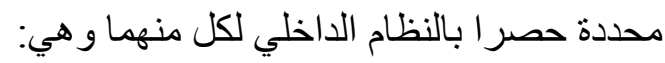

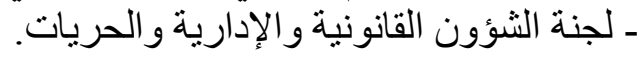

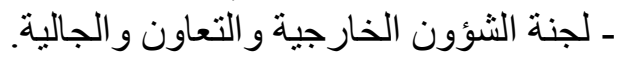
ـ ل لجنة الدفاع الوطني. ـ لجنة المالية و الميز النية. ـ لجنة الثؤون الإقتصادية و التنية التمية و الصناعة و التجارة و التخطيط.

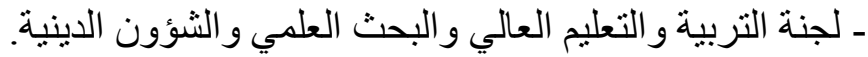
ـ لجنة الفلاحة والصيد البحري والعطائة العماية البيئة. ـ لجنة الثقافة و الإتصال و السياحة.

ـ لجنة الصحة والثؤونة الإنهان والإجتماعية و العمل و التكوين المهني.

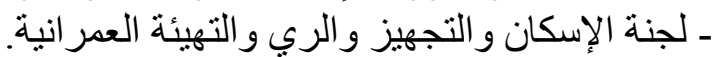

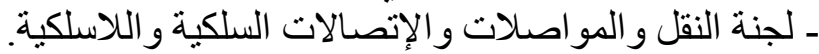

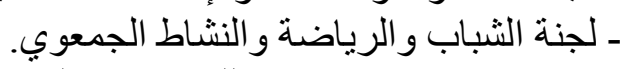

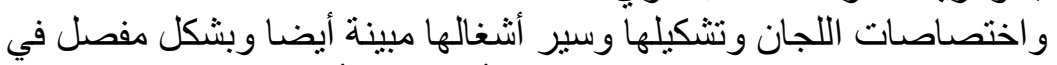

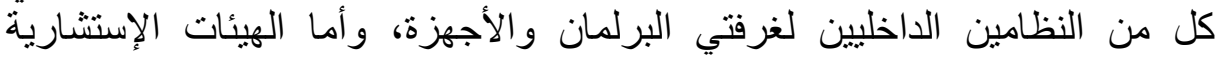

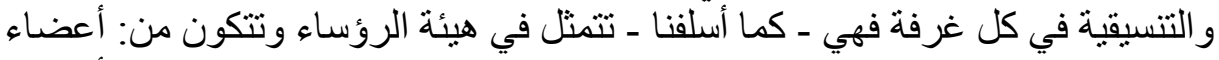

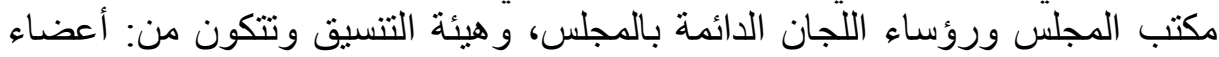

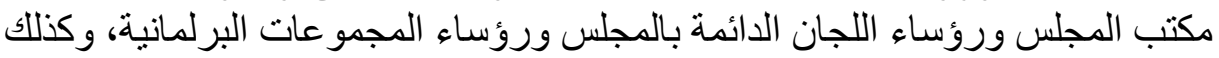


المجمو عات البرلمانية التي تتكون من : عشرة (10) أعضاء على الأقل داخل كل غرفة على حدة. (29)

هذا وتجدر الإشارة إلى أن سير عمل البرلمان بغرفتيه تحدده أحكام

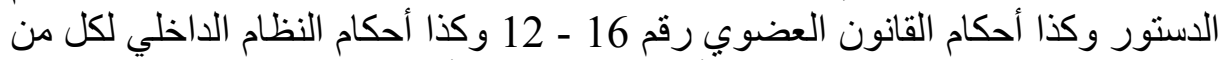

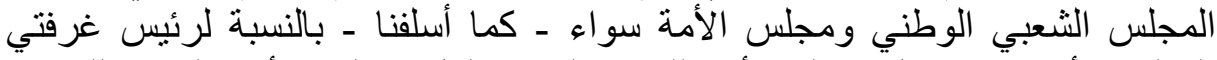
البرلمان أو مكتب كل مجلس أو اللجان الدائمة لكل مجلس، أو بالنسبة للهيئات

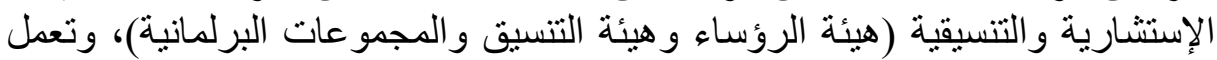

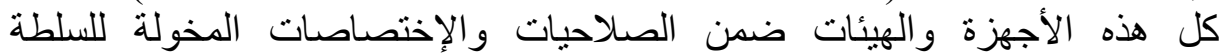

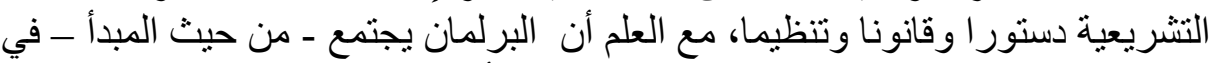

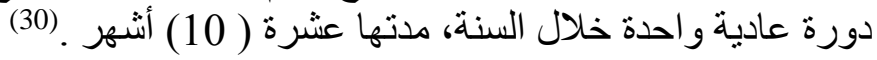

\section{ثُالثا: صلاحيات واختصاصات السلطة التشريعية: 1) صلاحيات واختصاصات السلطة التشريعية فئية في ميدان التثريع:}

1- التشريع عن طريق المبادرة باقتراحات القوانين:

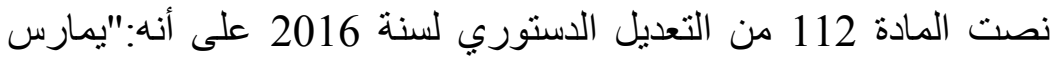

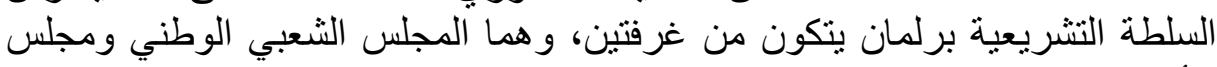

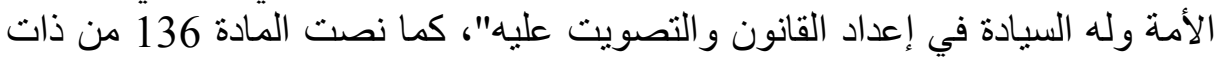

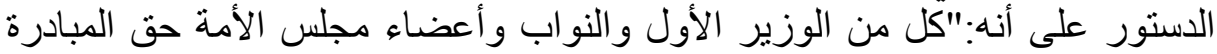

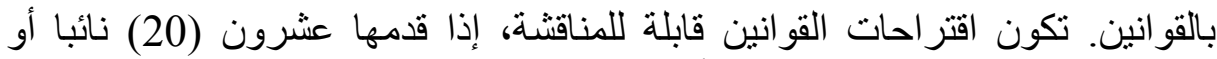

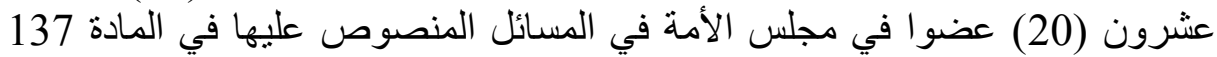

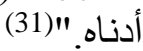

ويلاحظ هنا، أنه ولأول مرة تم منح حق المبادرة باقتراحات قوانين

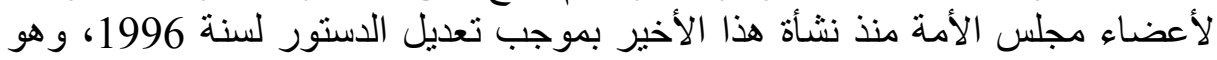

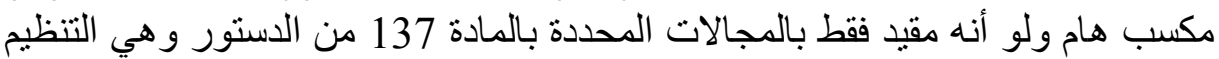

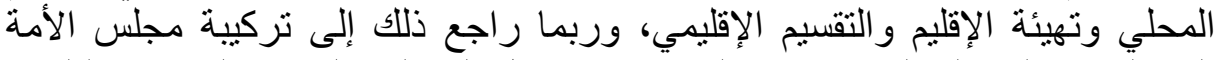

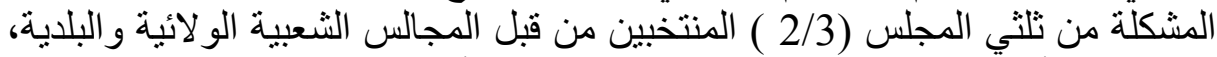

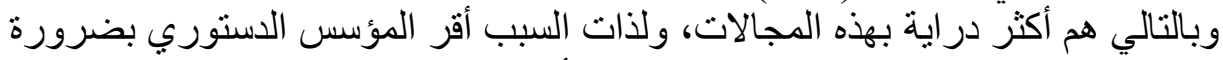

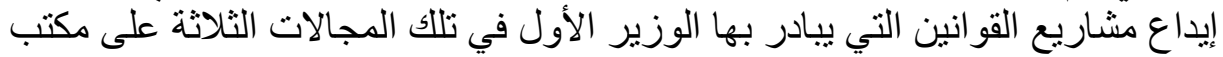

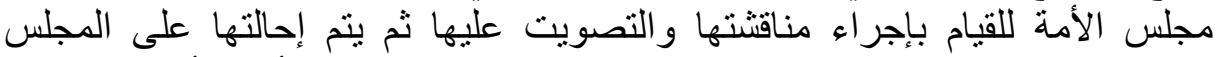

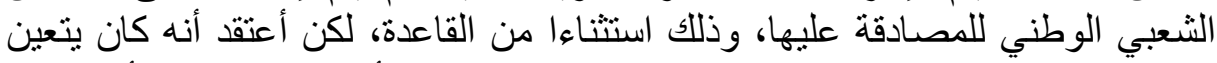

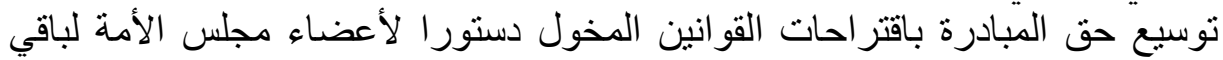

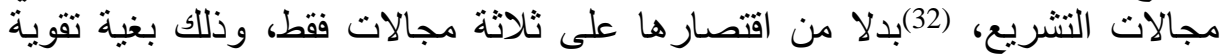

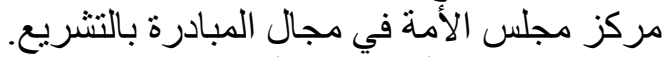

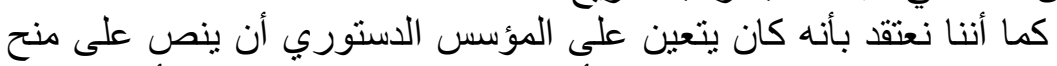

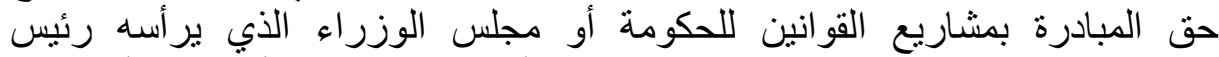

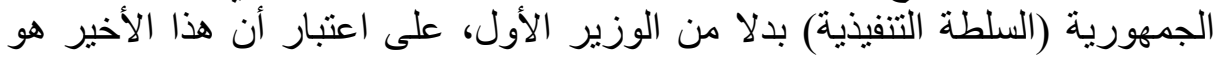

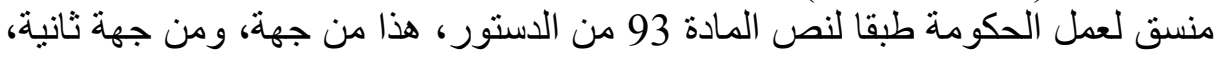

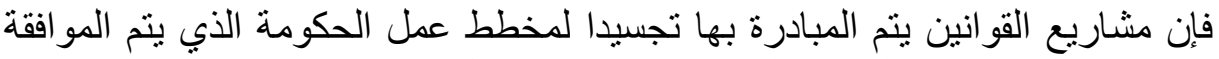

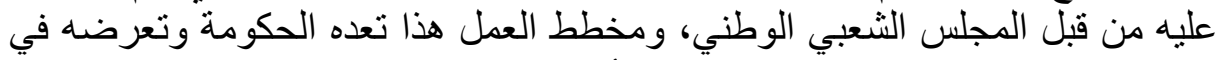

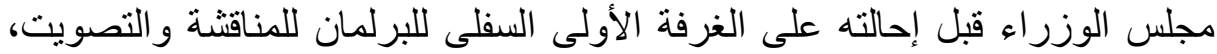
(33) ومن جهة ثالثة، فإن نص المادة 99 من الدستور لم تدرج - بصفة لإلى خاصة ـ صلاحية 
المبادرة بمشاريع القوانين ضمن الصلاحيات المخولة حصريا للوزير الأول، كما أن

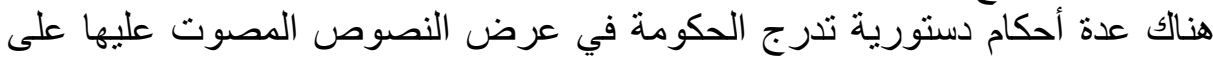

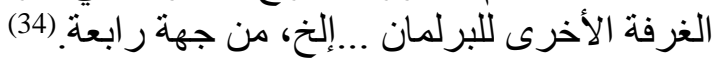

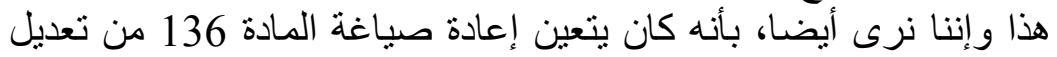

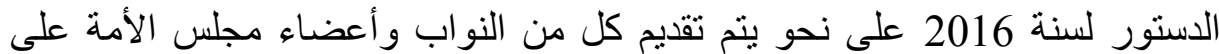

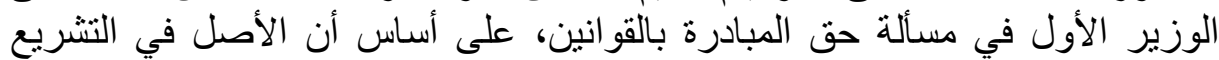

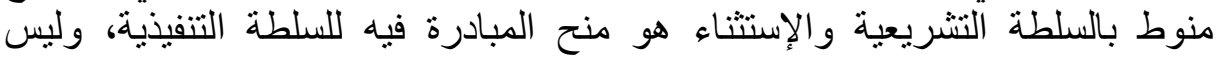

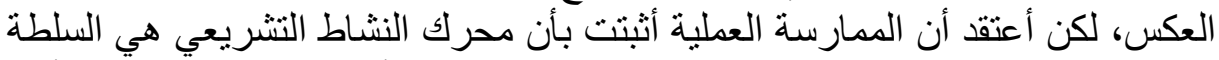

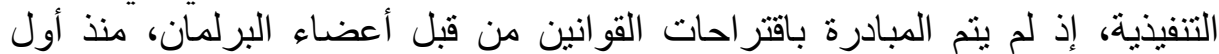

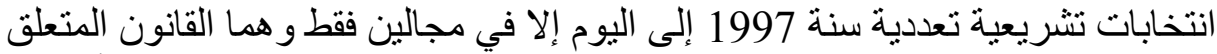

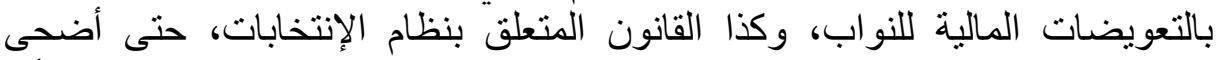

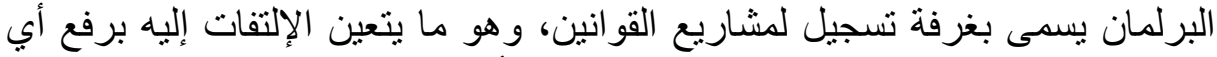

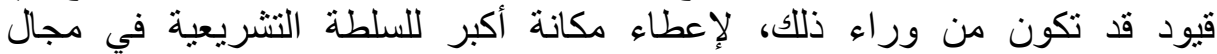

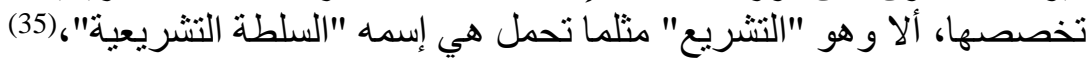

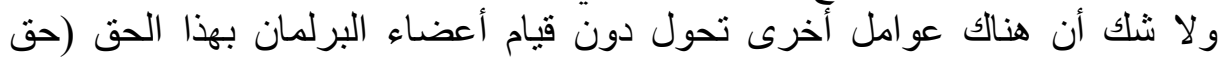

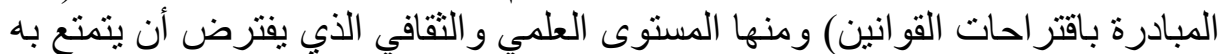

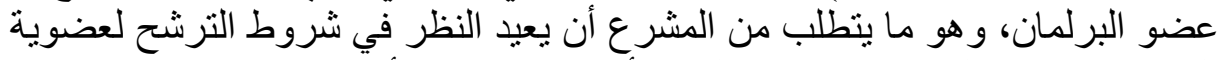

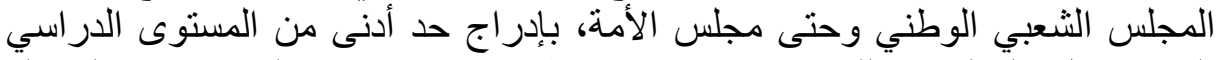

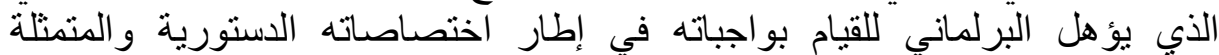

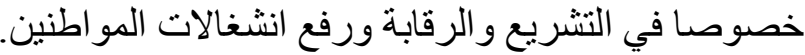

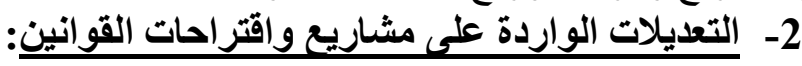

"لقد كانت التعديلات، و لا تزال، وسيلة تملكها البرلمانات للضغط على الته

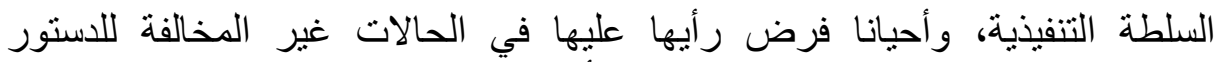

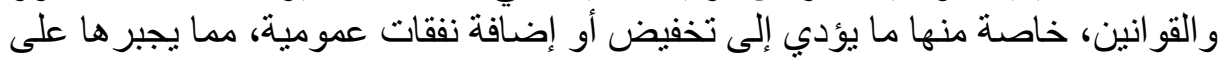

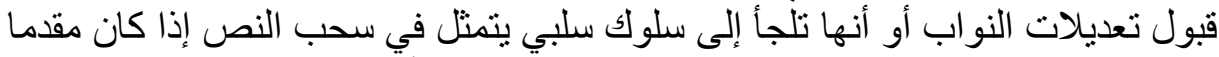

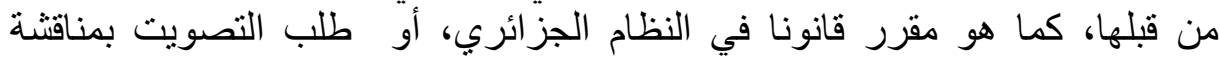

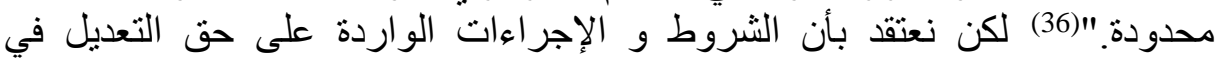

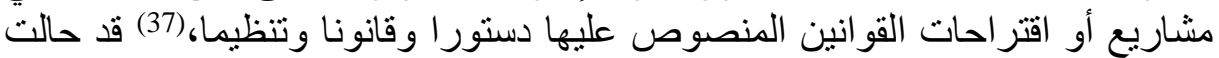

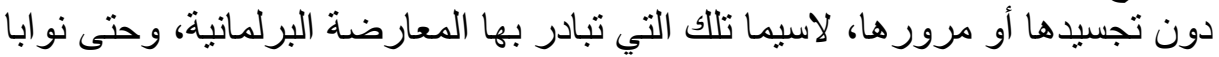

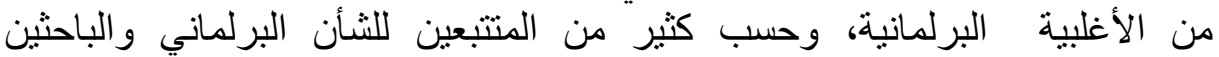

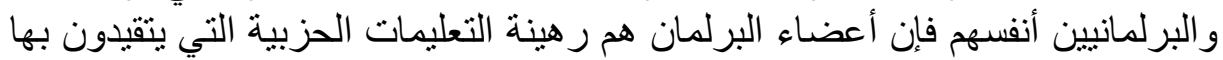

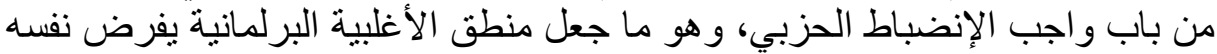

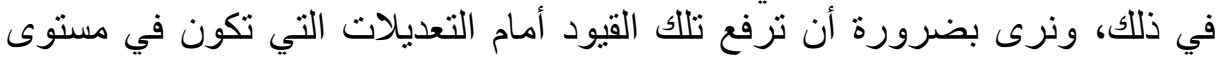

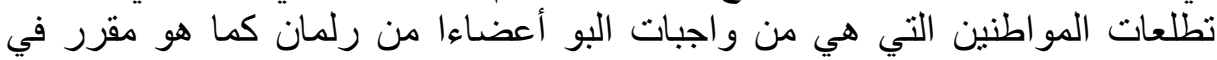
3- اللجنة المتساوية الأعضاء آلية لتسوية الخلاف بين غرفتي

الدستور . (38)

تتص المادة 138 من تعديل دستور 2016 على أنه "... تعرض الحكومة

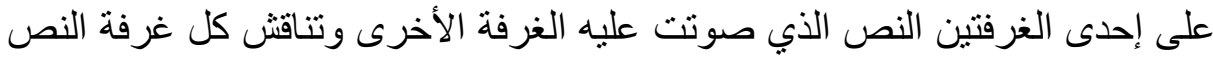

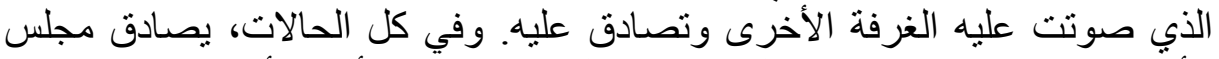

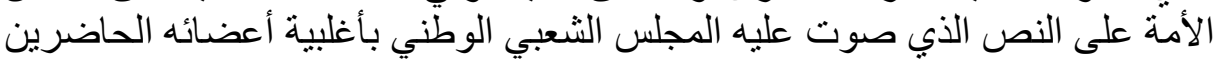
بالنسبة لمشاريع القو انين العادية أو الأغلبية المطلقة بالنسبة لمشاريع القية القوانية النين العضوية. 
وفي حالة حدوث خلاف بين الغرفتين، يطلب الوزير الأول اجتماع لجنة متساوية

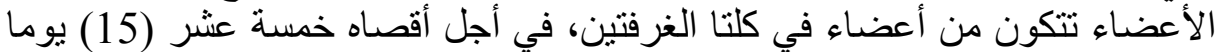

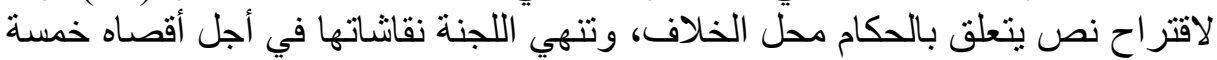
عشر (15) يوما. تعرض الحكومة هذا النص على الغرفتين للمصادقة عليه، و لا يمكن

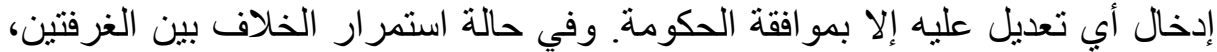

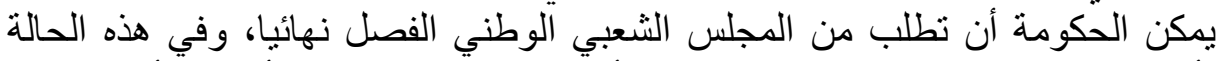

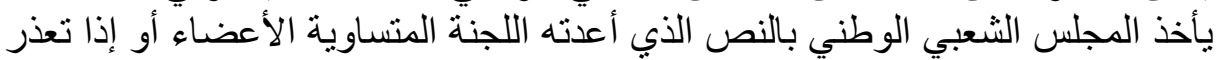

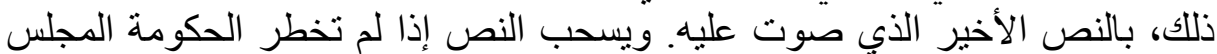

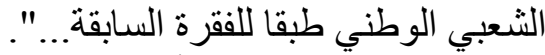

نلاحظظ هنا، بأن الاستور قالفة منح السلطة التقديرية للجوء إلى اللى آلية اللجنة

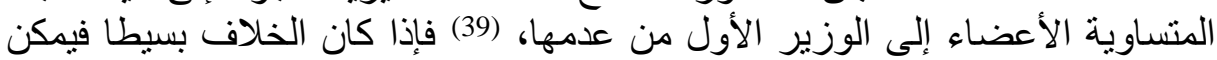

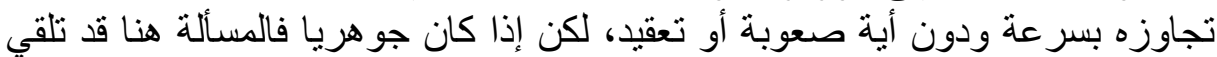

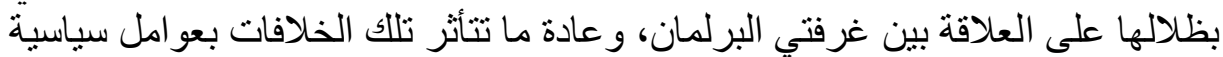

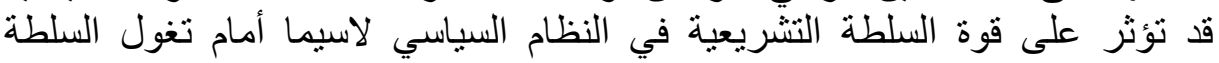

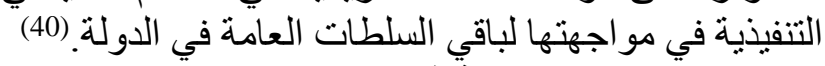
4- المشاركةٌ في تعديل الاستور:

بالرجوع إلى أحكام الدستور، الباب الرابع منه، نجد المؤسس الدستوري

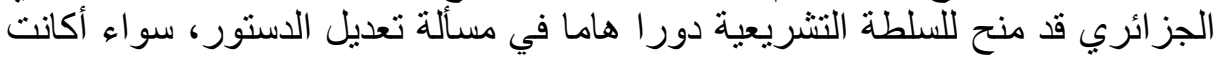

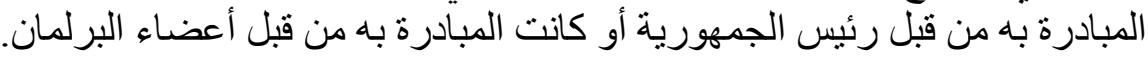

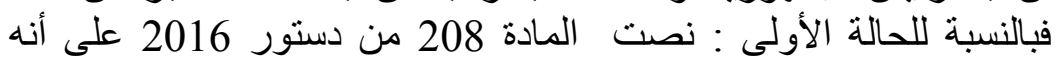

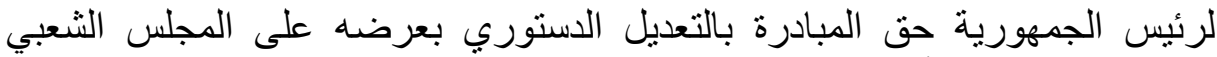

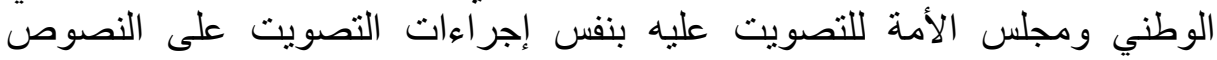

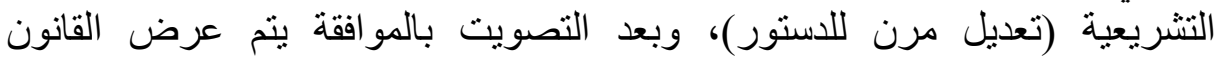

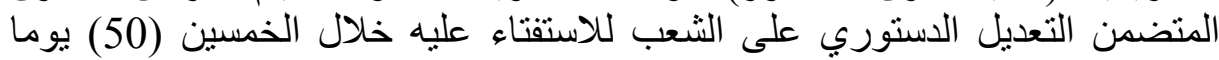

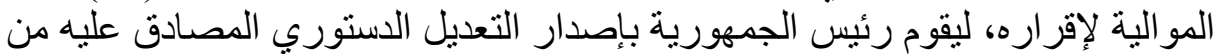

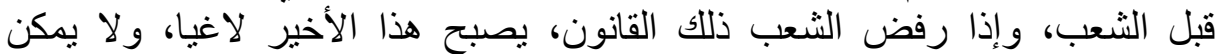

عرضه من جديد على الثعب خلال تللك الفترة التشريعية (العهدة الإنتخابية). (41)

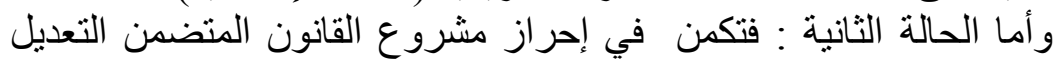

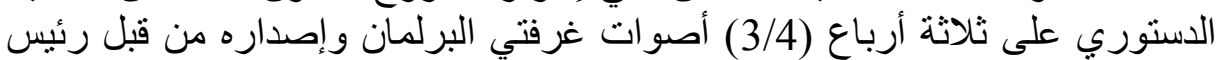

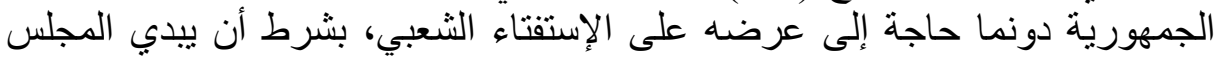

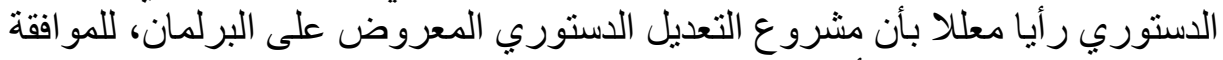

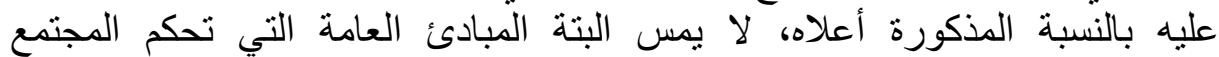

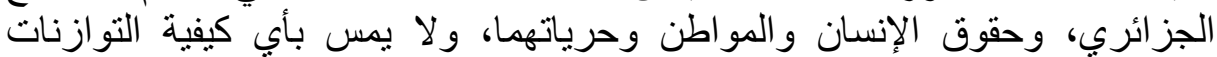

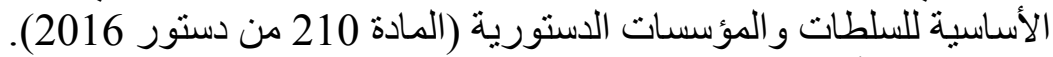

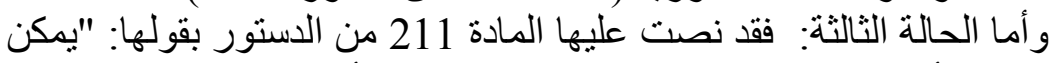

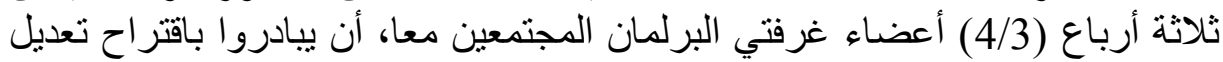

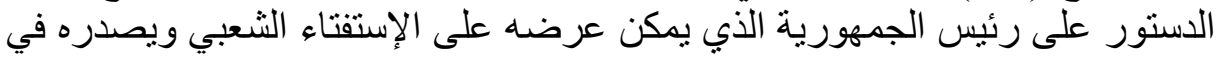
وون الأهمية بمكان القول بأنه وإن كانت الحالتين الأوليتين لمشاركة حالة المو اققة عليه".

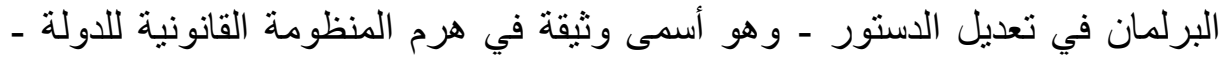

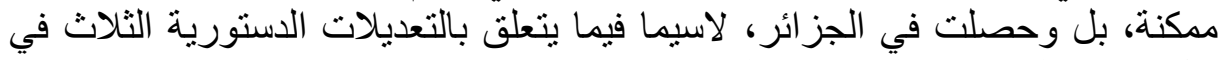

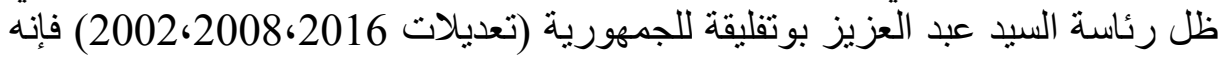

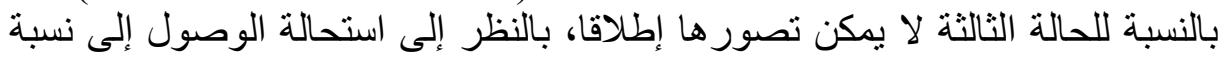

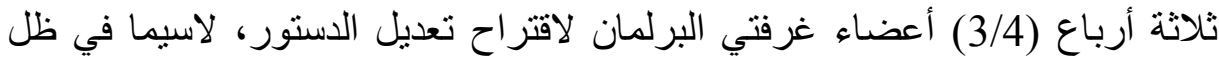


التركيبة السياسية للغرفة الأولى السفلى للبرلمان التي تضم فسيفساء من النواب المنتمين

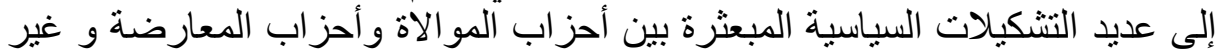

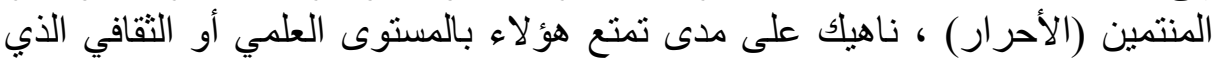

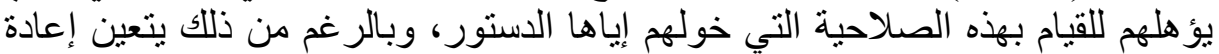

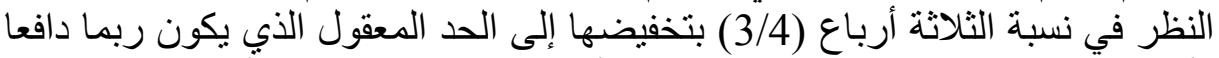

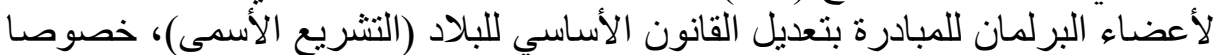

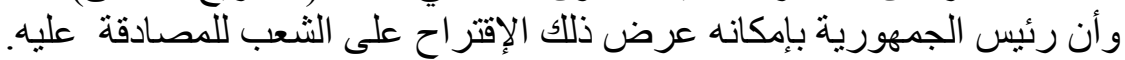

\section{2) صلاحيات واختصاصات السلطة التشريعية في ميدان الرقابة على أعمال \\ الحكومة: الت}

1- وسائل الرقابة البرلمانية التى تترتب عليها المسؤولية السياسية

\section{للحكومة بصفة مباشرة أمام البرلمانية التهاني}

\section{أ- مناقشة مخطط عمل الحكومة:}

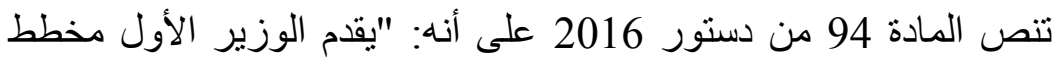

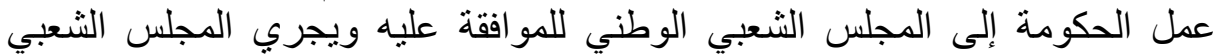

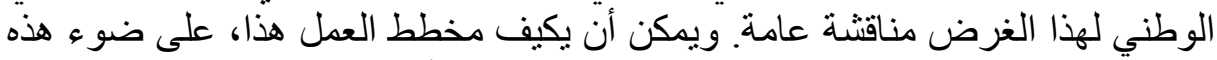

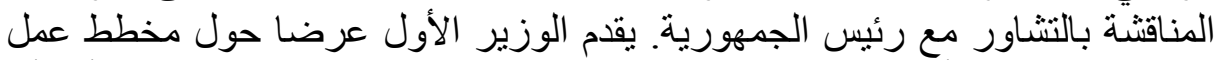
الحكومة لمجلس الأمة مثلما و افق عليه المجلس الثعبي الوطني. لأولئ يمكن مجلس الأمة أن

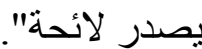

يستشف من النص الدستوري الدذكور أعلاه. بأن الحكومة لا يمكنها

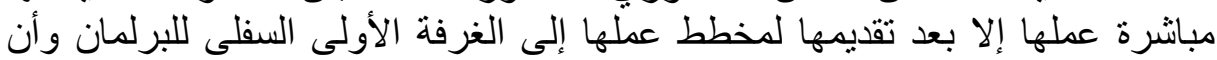

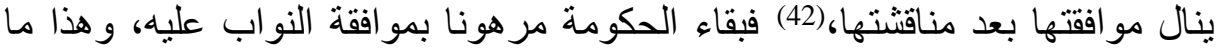

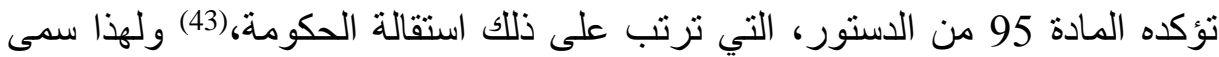

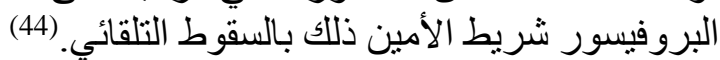

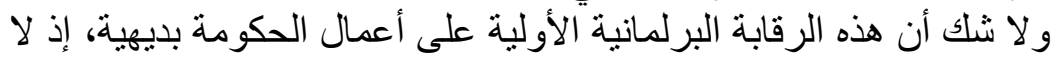

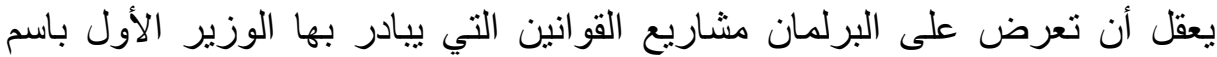

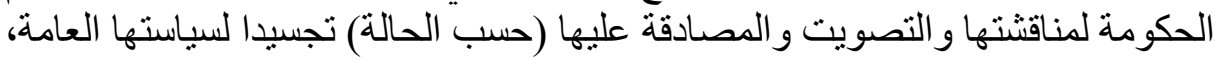

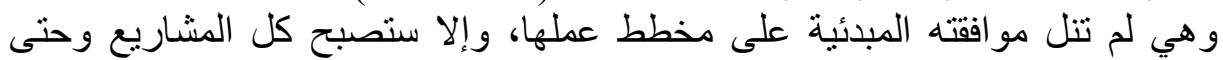

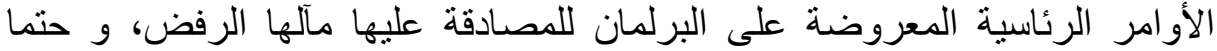

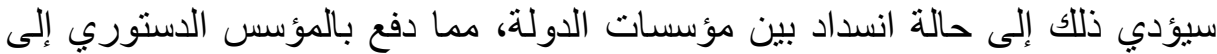

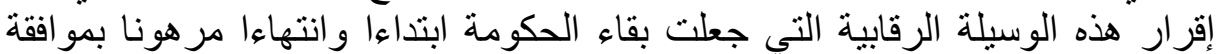

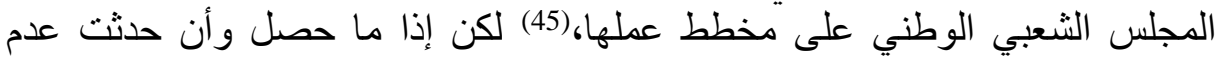

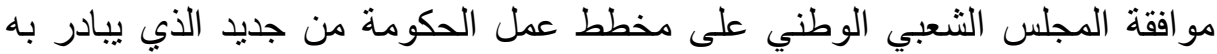

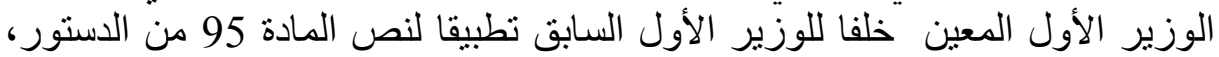




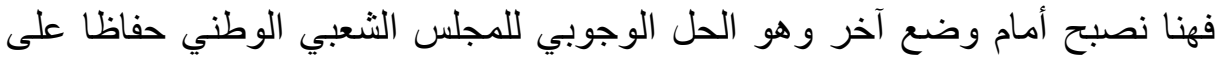

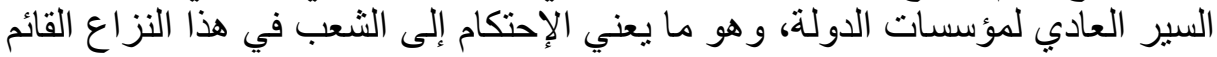

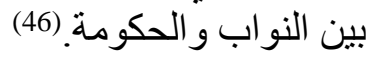

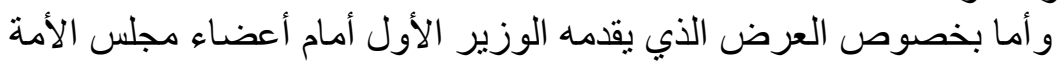

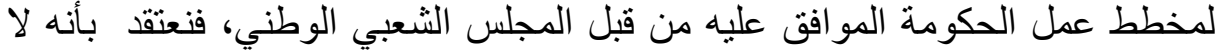
يتماثتى مع التوجه الجديد للمؤسس الدستوري في التعديل الدستوري لسنة

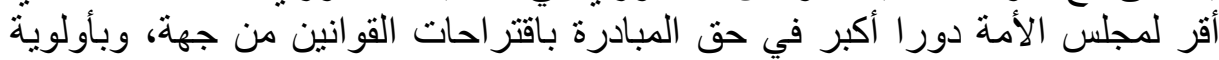

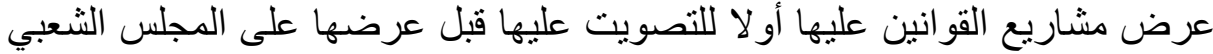

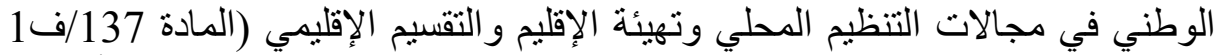

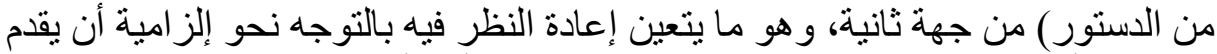

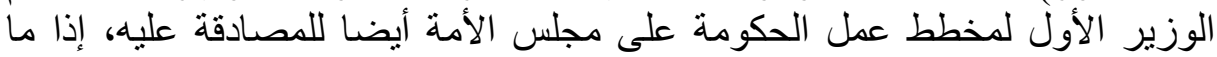

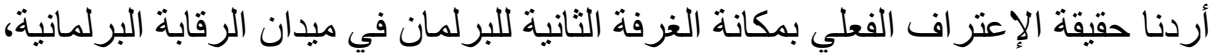

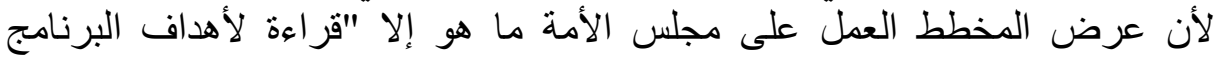
ومحاوره الكبرى التي اطلع عليه المجلس الثعبي الوطني، بكل الإنة تفصيلاتها وجزئياتها وناقثها وو افق عليها". (47)

\section{ب- مناقشة بيان السياسة العامة و التصويت بالثقة:}

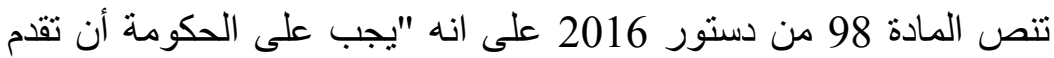

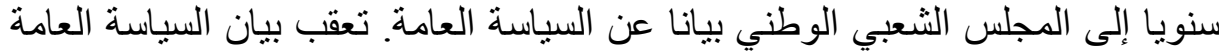

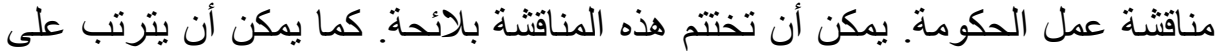

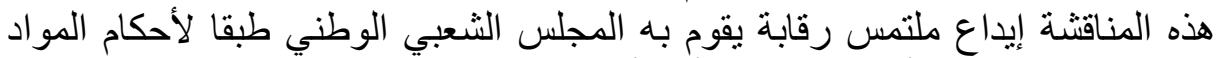

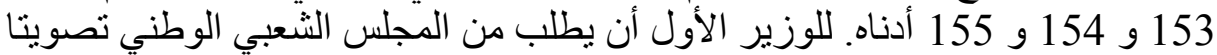

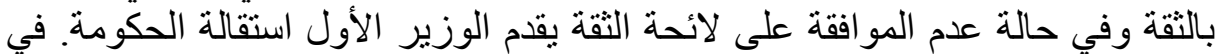
هذه الحالة يمكن رئيس الجمهورية أن يلجأ قبل قبول الإستقالة إلى أحكام المادة 147

أدناه.

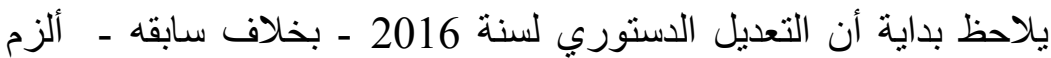

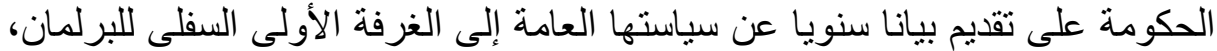

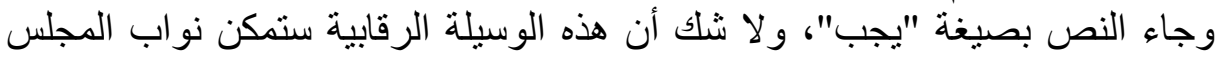

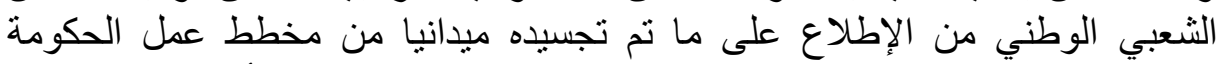

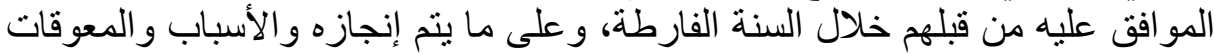
التي أدت إلى ذلك ناهيك عن الآفاق المستقبلية لاستدراك التأخر في الإنجاز أو العجز التالئ

لكن نعتقد بأنه كان على المؤسس الدستوري أن يجبر الحكومة أن تقدم العاءم العباء

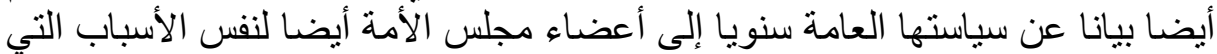

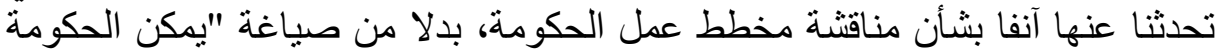

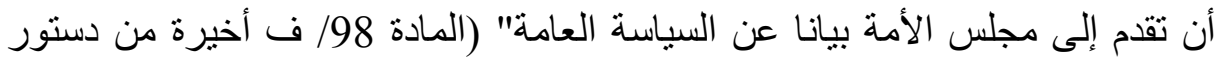

في سياق المتصل، فإن إحاطة المشرع الجزائري ملتمس الرقابة بقيود

وشروط دستورية وقانونية وتتظيمية، (48)قد جعلت منه مجرد وسيلة رقابية التية عديمة التية

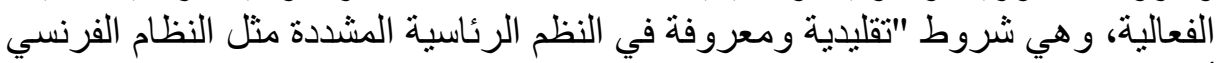

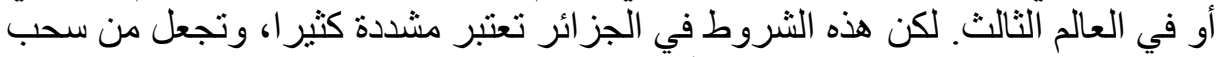

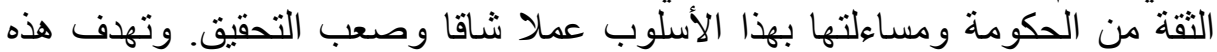


التقنيات إلى تحقيق استقرار الحكومة واستبعاد الأزمات الحكومية بمنع البرلمان من التهور ضد الحكومة و هذا ما يسمى بـ "العقلنة البرلمانية التمانية"(49).

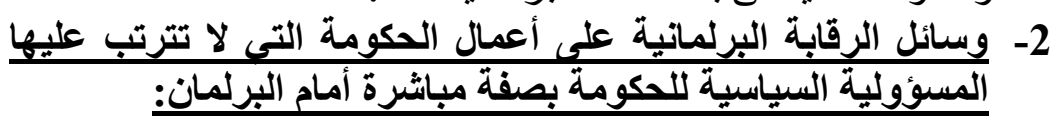

أ) السؤال:

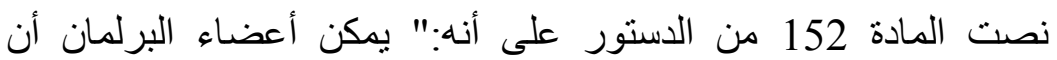

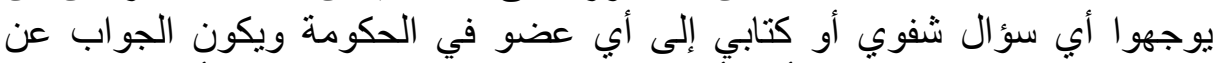

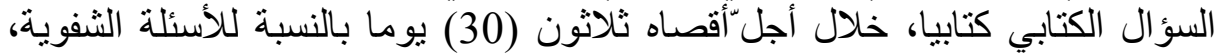

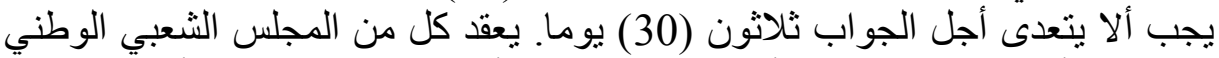

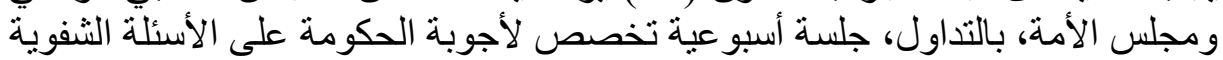

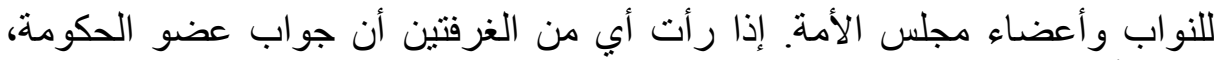

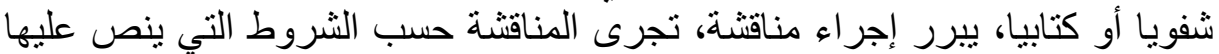
النظام الداخلي للمجلس الشعبي الوطني ومجلس الأمة. تنشر الأسئلة والأجوبة طبقا

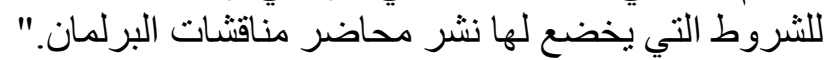

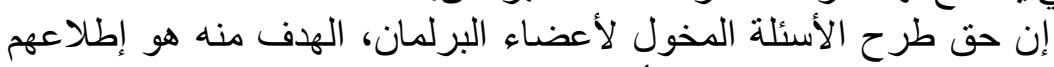

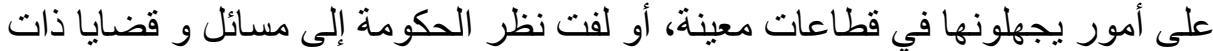

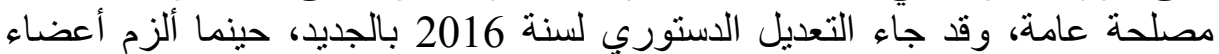

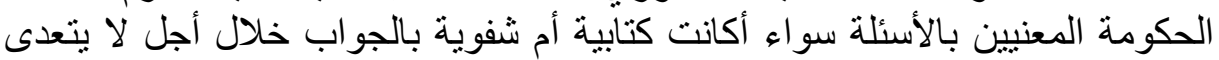

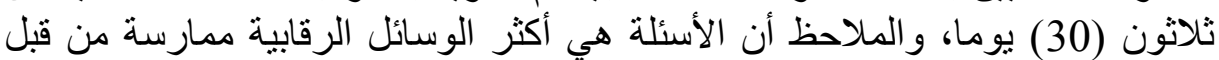

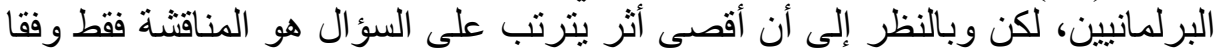

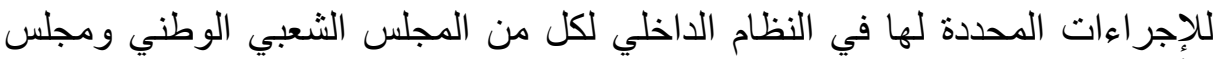

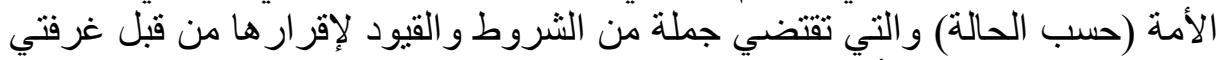

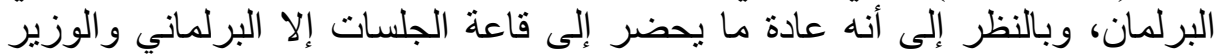

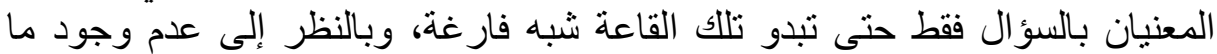

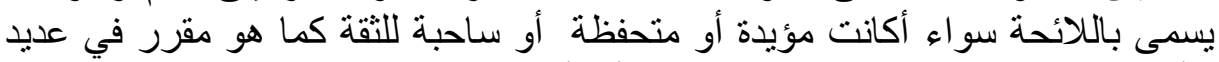

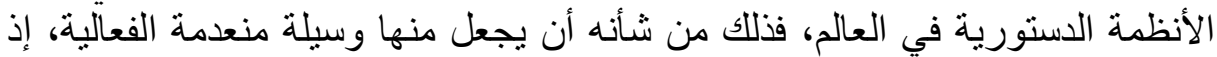

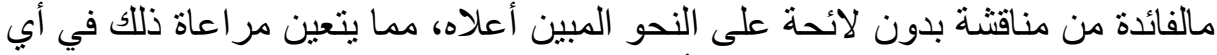

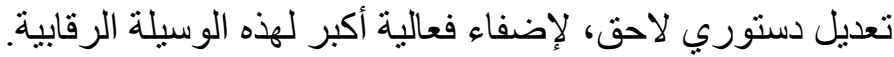

ب) الإستجواب:

تتص المادة 151 من دستور 2016 على أنه:"يمكن أعضاء البرلمان استجو اب الحكومة في إحدى قضايا الساعة. ويكون الجواب خلادل أجل أقصاه ثنلاثون أنصاء

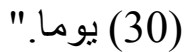

يلاحظ في الفقه والقانون الدستوري المقارن بأن الإستجو اب هو من أخطر

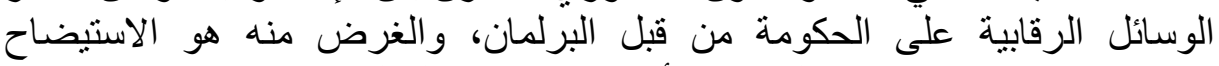

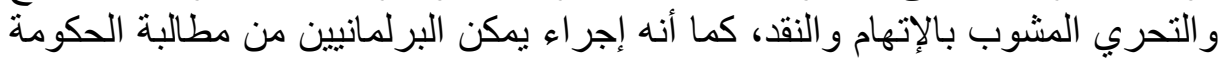
توضيح وشرح أسباب تصرفها في قضية من قضايا الساعة، والغيات والغاية والهدف من التصرف الذي أقدمت عليه الحكومة في تلكي القضية.

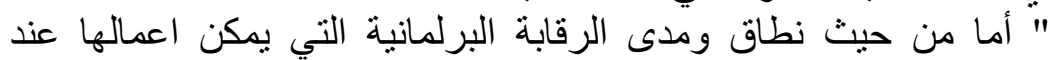

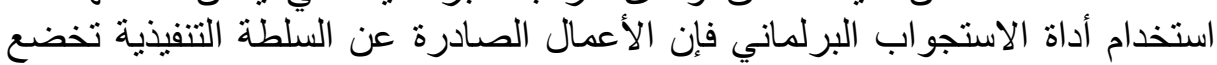

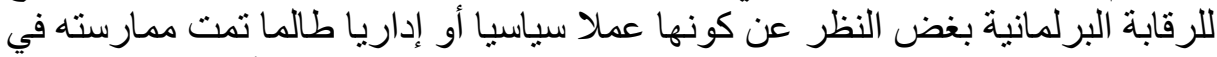

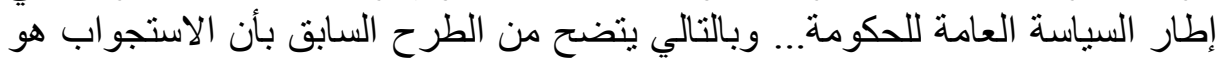


في حقيقته مناقثة لموضوع يحمل صفة الاتهام لمن وجه لهام له، ومن الممكن أن تثار

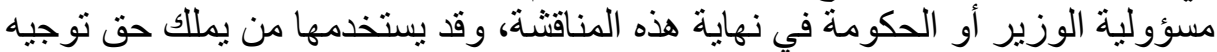

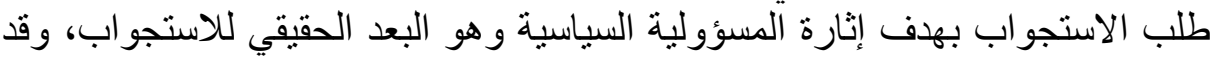

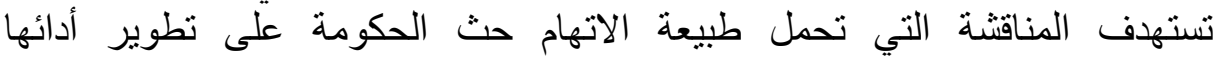

وتحسينه". (51)

لكن في النظام الدستوري الجزائري فإن الاستجو اب شأنه شأن السؤال لا لا

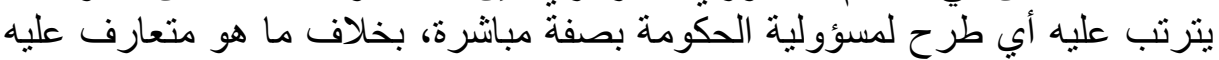

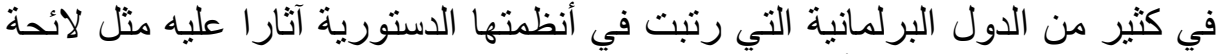

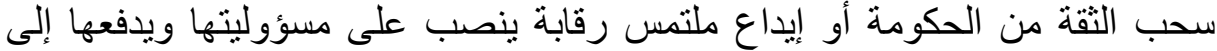

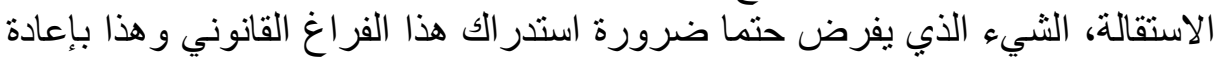

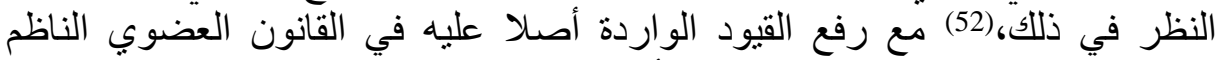
للعلاقة بين البرلمان و الحكومة وكذا في أحكام النظامين الداخلّيين لغرفتي البرلمان البران.

\section{ج) لجان التحقيق:}

تناول المؤسس الدستوري الجزائري في الباب الثالث للاستور المعنون بـ التـائ

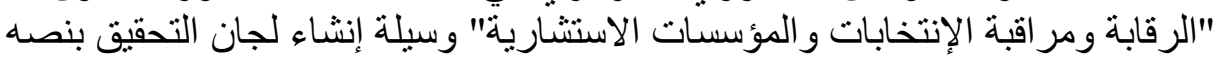

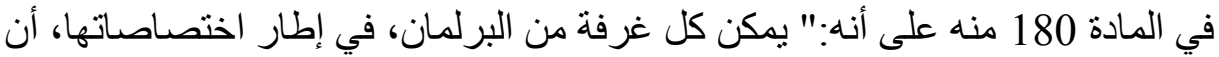

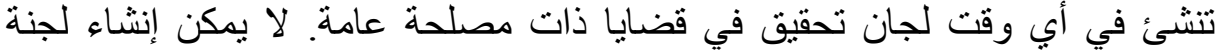
تحقيق بخصوص في وقائع تكون محل إجر اء قضاء قضائي". لا شك أن لجان التحقيق البرلمانية تكتسي أهمية بالغة إلغة، ذلك أنهان أنها تسمح

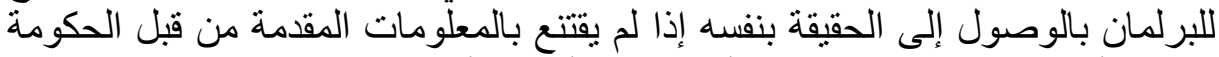

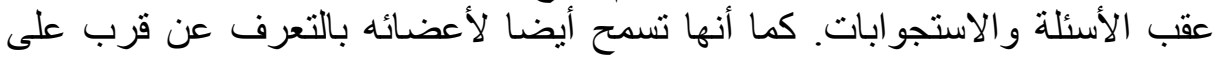

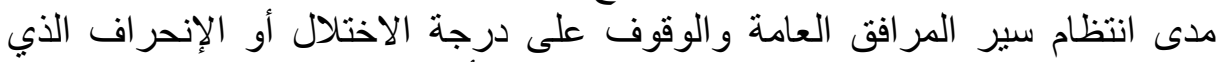

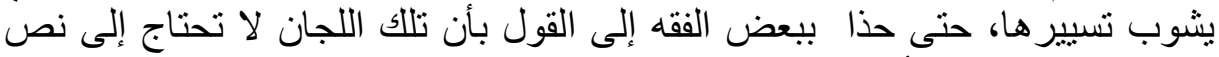

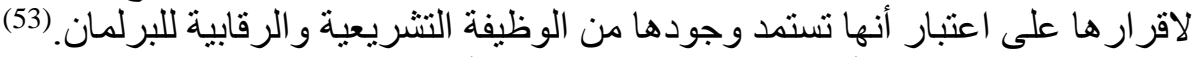

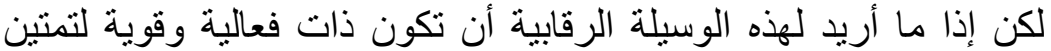

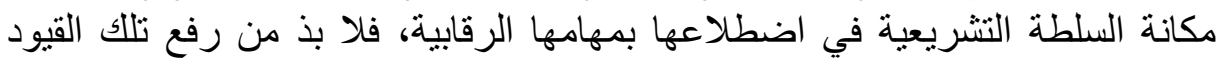

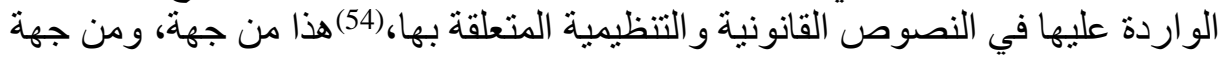

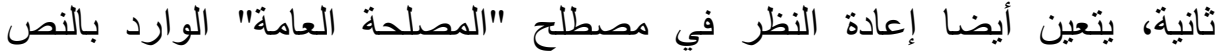

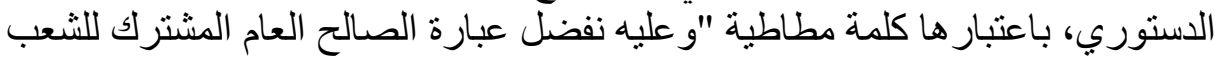

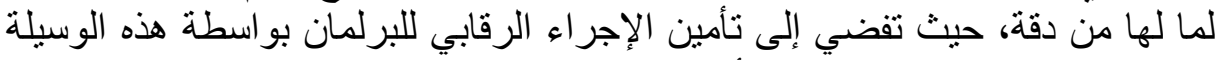

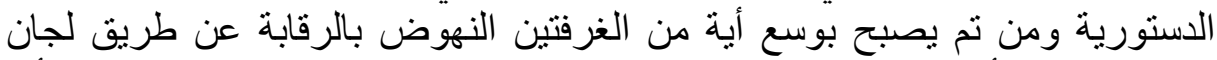

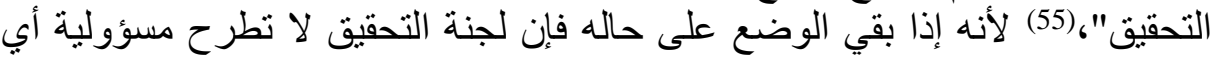

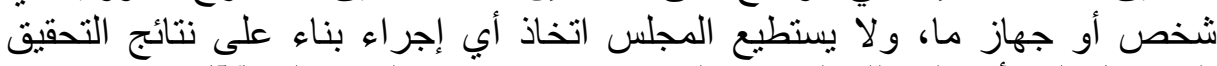

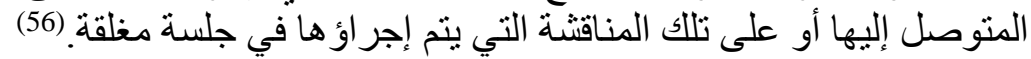

\section{د) استماع اللجان إلى أعضاء الحكومة:}

تم النص على إمكانية استماع لجان البرلمان إلى أعضاء الحكومة بموجب المادة 151/فقرة أخيرة من الدستور على إنيانية

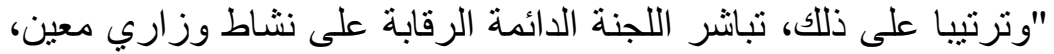

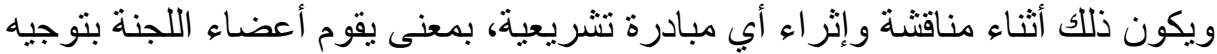

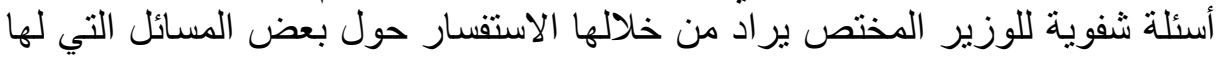


ارتباط بالمشروع أو اقتراح القانون محل الدراسة، وبالتالي، يتولى الوزير المشرف

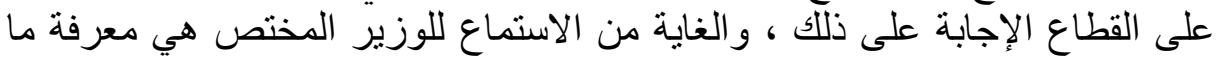

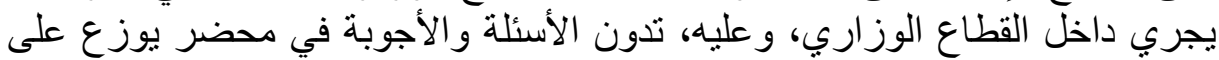

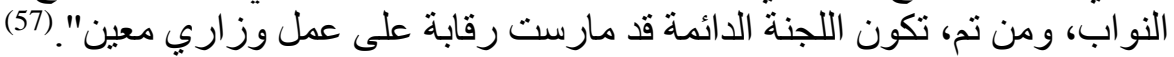

0) مناقشة السياسة الخارجية:

نصت المادة 148 من تعديل الدستور لسنة 2016 على أنه:" بمكن البرلمان

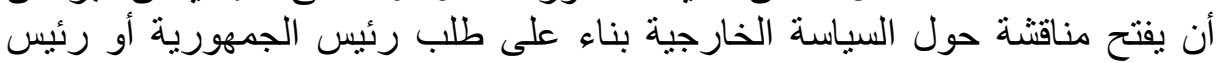
إحدى الغرفتين.

يمكن أن تتوج هذه المناقتشة، عند الاقتضاء، بإصدار البرلمان، المنعقد بغرفتيه المجتمعتين معا، لائحة يبلغها إلى رئيس الجمهورية".

يلاحظ عند استقراء نص المادة 148 من الدستور بأن رقابة البرلية البرلمان هنا

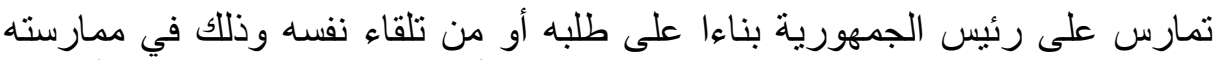

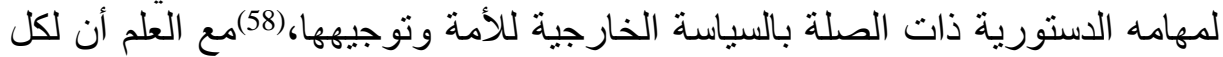

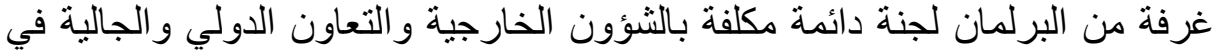

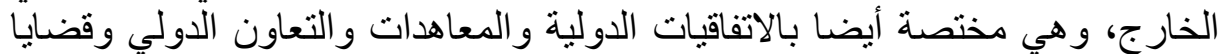

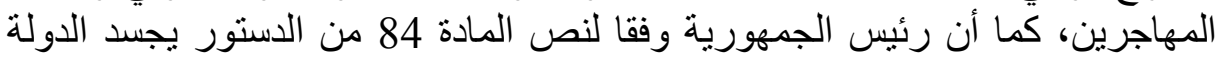

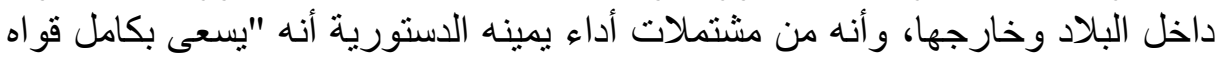

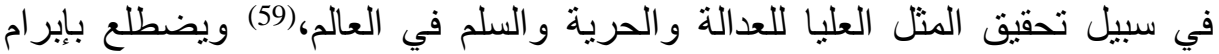
المعاهدات الدولية ويصادق عليها،(60)كما يصادق رئيس الجمهورية علية التى الفاقيات

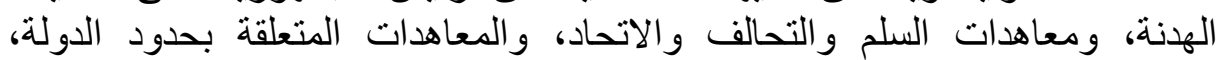

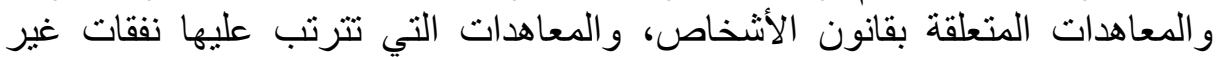

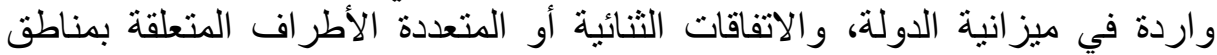

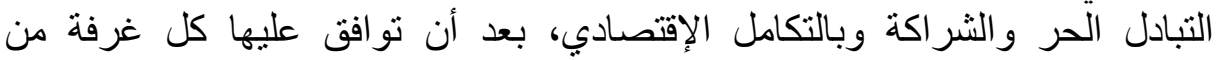

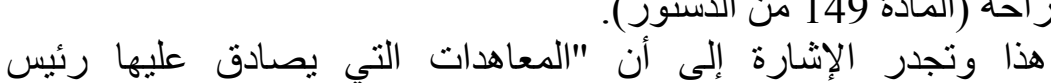

الجمهورية، حسب الثروط المنصوص عليها في الدستور تسمو على القانون".(61)

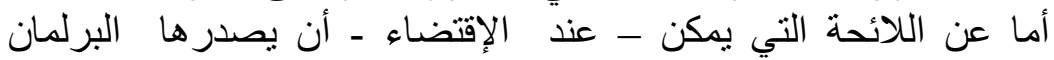

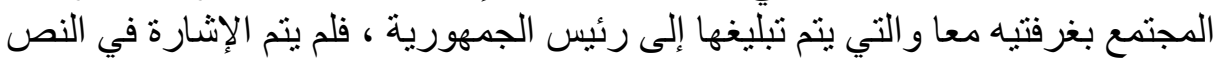

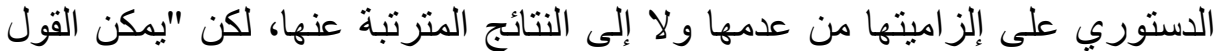

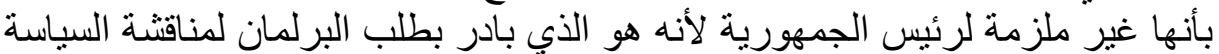

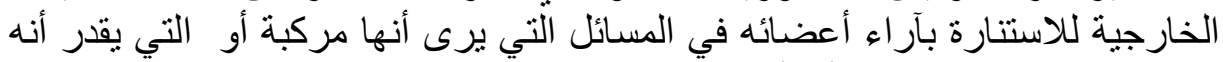

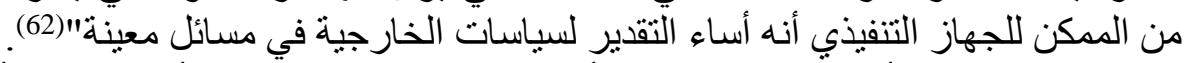
ونعتقد بأنه ولا ضفاء قيمة أكبر لهذه الوسيلة الرقابية، أن تعمم مسألة

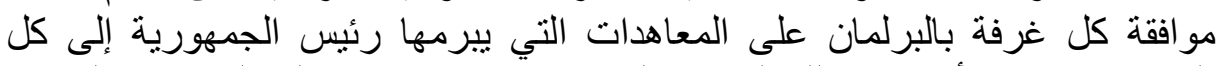

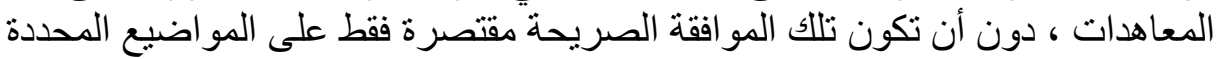

\section{و) -للـنة: التصويت على مشروع قانون المالية و مراقبة استعمال الإعتمادات المالية}

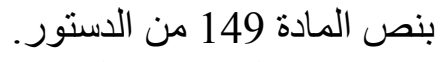

باستقرار نص المادة 140 و المادة 141 من التعديل الدستوري المتضمنتين

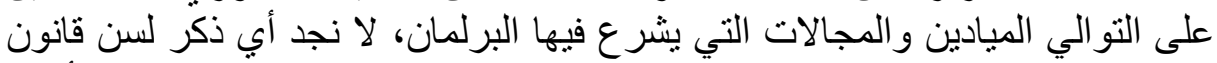

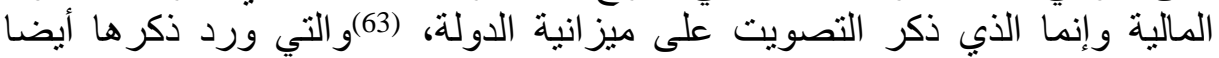

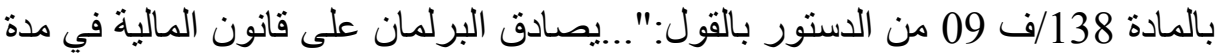




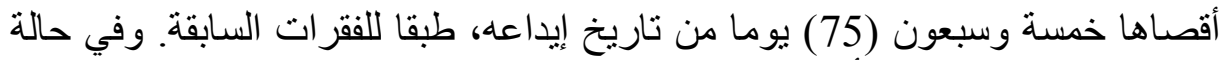

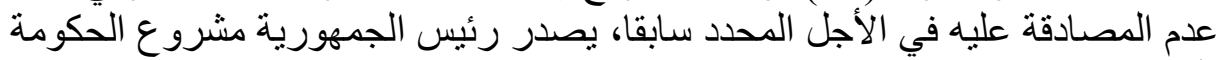

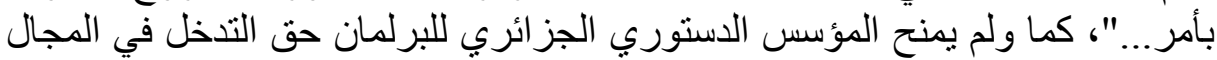

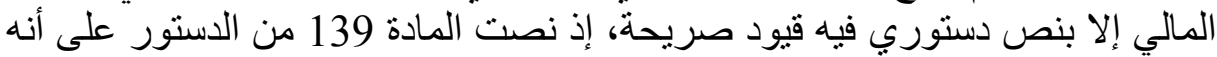

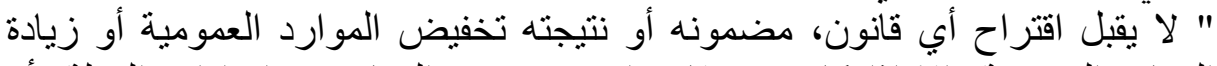

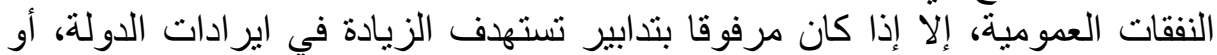

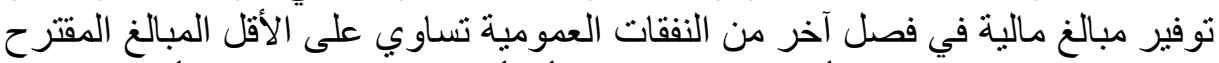

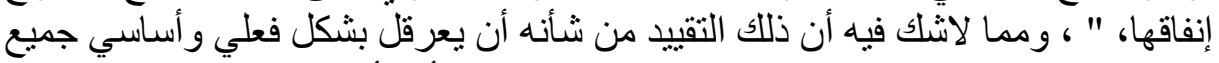

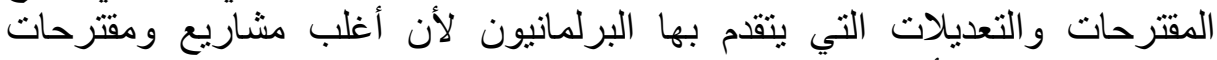

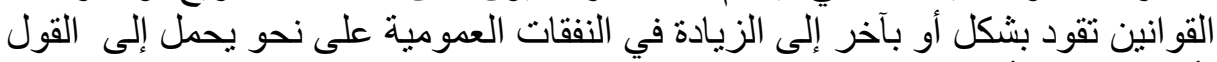

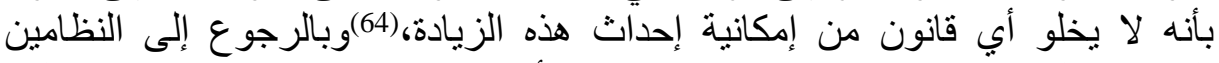

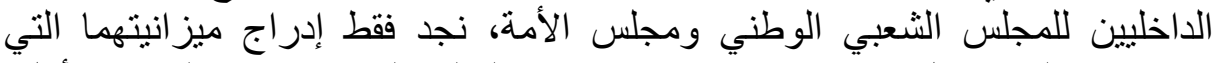

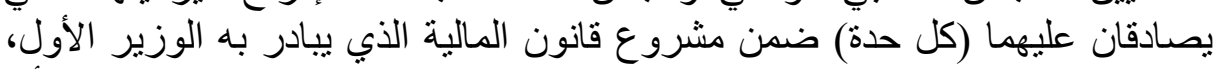

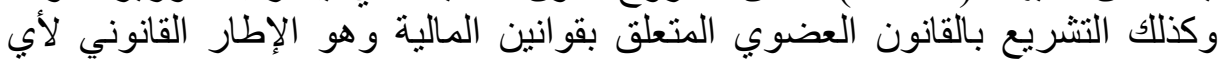

قانون مالية (ميز انية الدولة السنوية). (65) العنوية

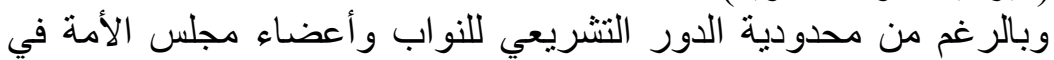

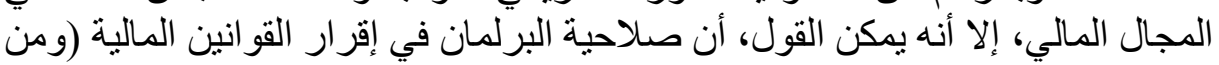

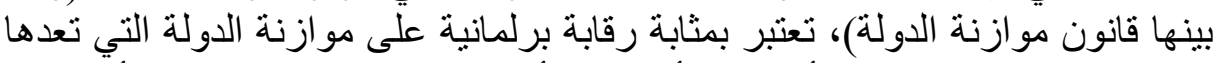

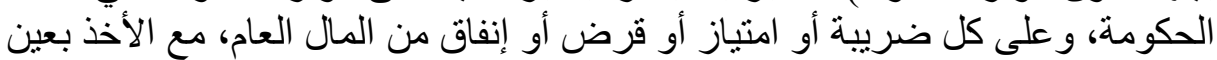
الاعتبار أهية دور السلطة التنفيذية في إصدار القيار القوانين التي يقرها البران البرلمان، وفقا

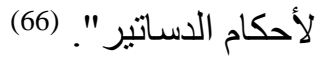

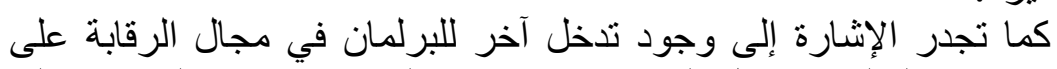

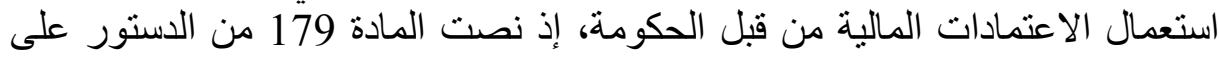

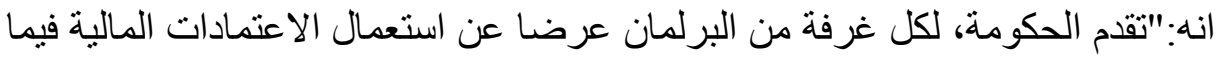

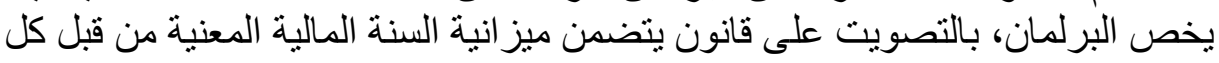

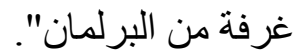

إن الحكم على مكانة السلطة التشريعية في أي نظام سياسي لأي دولة، لابذ

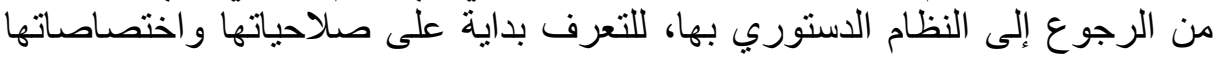

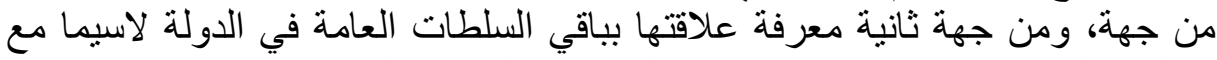

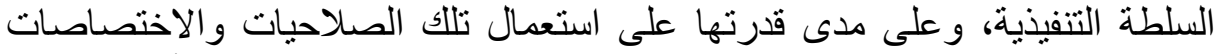

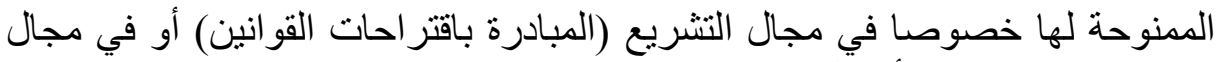
الرقابة البرلمانية على أعمال الحكومة فئة

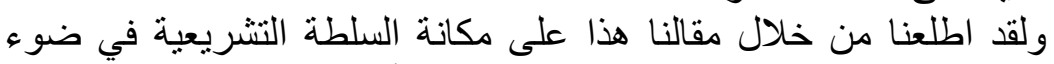

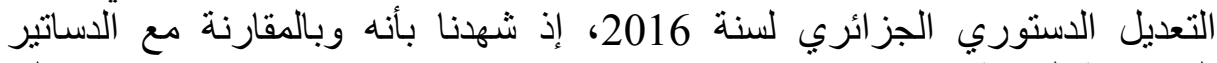

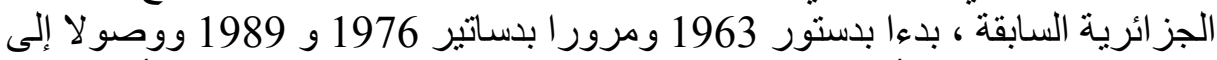
دستور 1996، نجد بأن مكانة السلطة التشريعية في التعديل الدستوري التباني الأخير لسنة

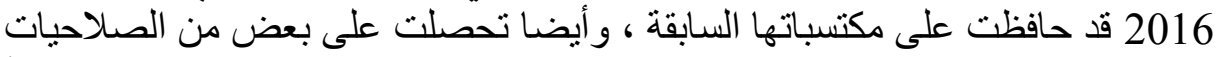

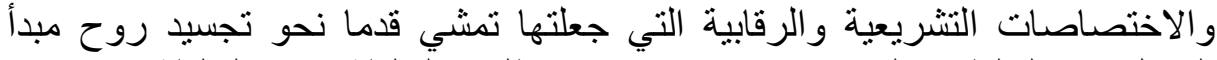

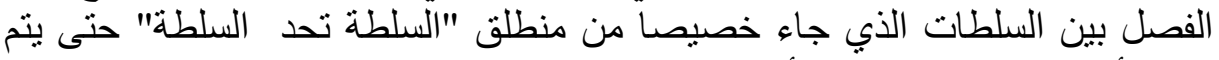
تفادي أي انحر اف في السلُطة أو تجاوز لهاء خلها هذا وقد خلصنا إلى جملة من النتائج التي يمكن إيجاز ها لها كما يلي:

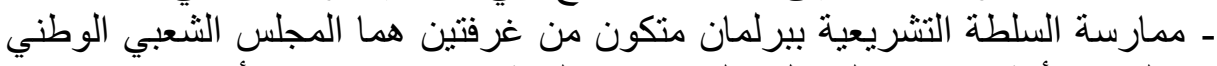

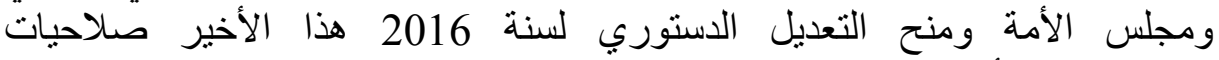
واختصاصسات أوسع من تللك التي كانت مقررة لله بموجب دستور 1996 جعل من 


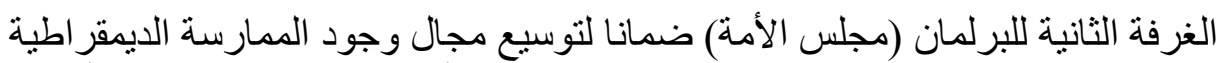

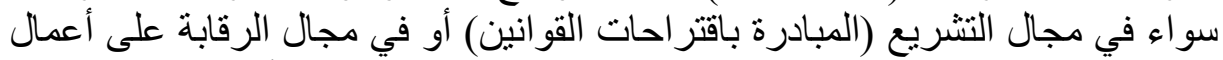

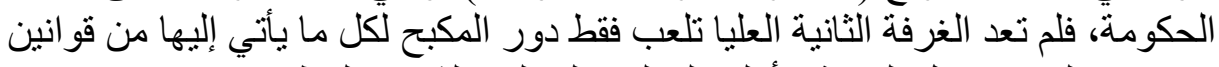

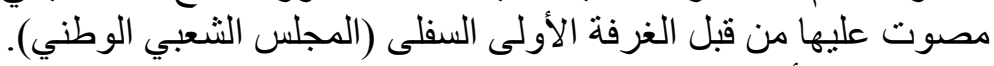

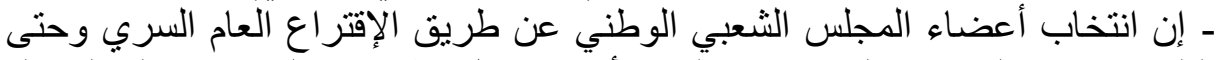

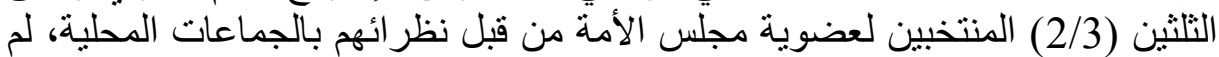

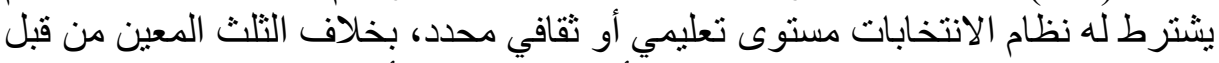

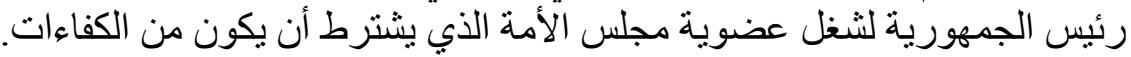

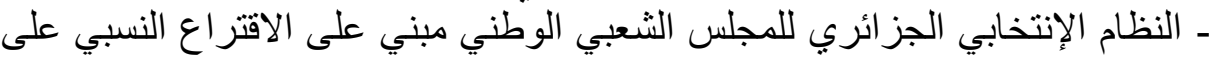
القائمة.

- يتمتع كل من المجلس الثعبي الوطني ومجلس الأمة بالاستقلالية الإدارية و المالية.

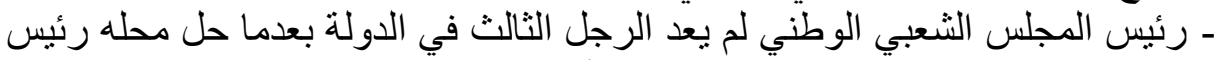

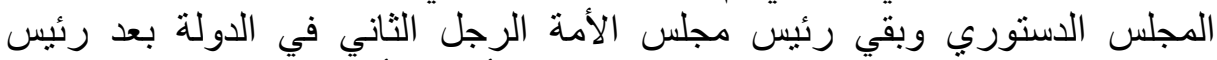

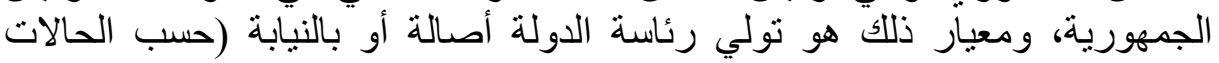
و الشروط و المقتضيات الدستورية).

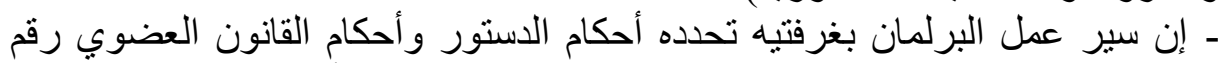

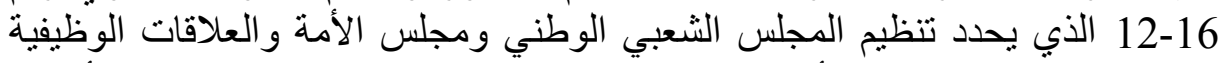

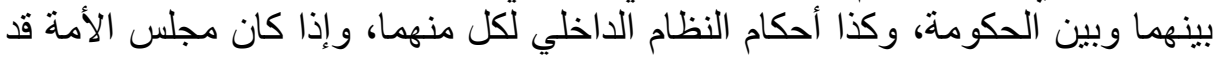

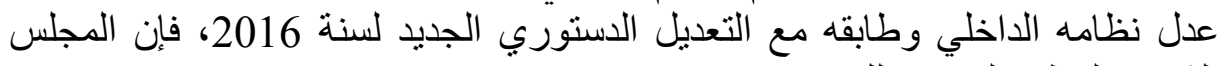

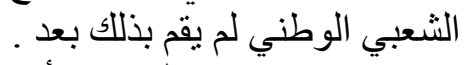

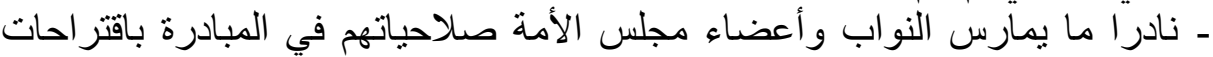

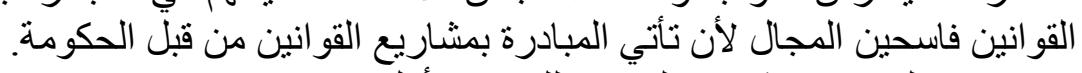

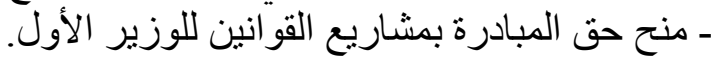

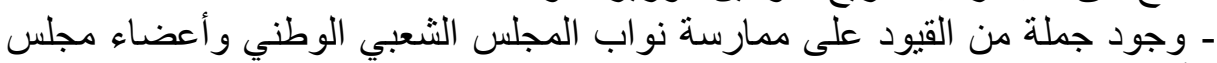

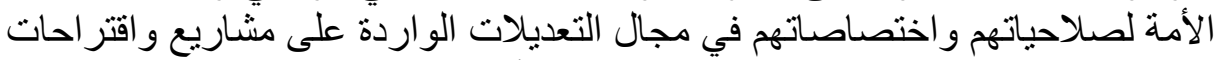

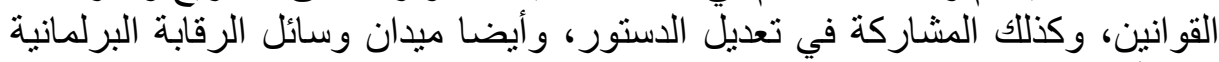

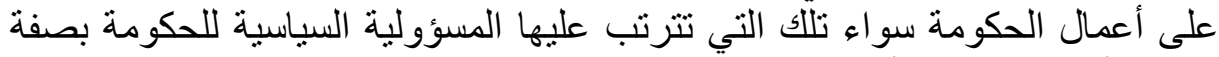

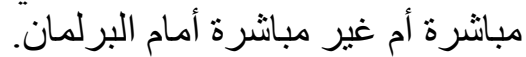

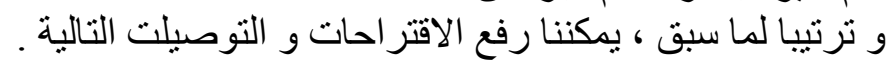

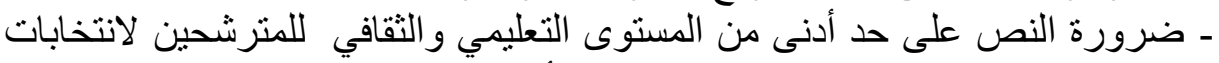

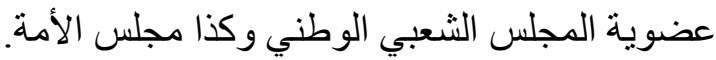

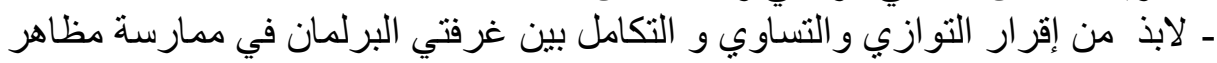

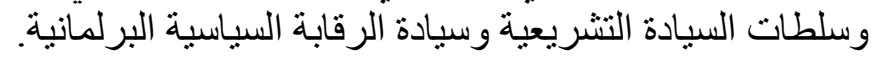

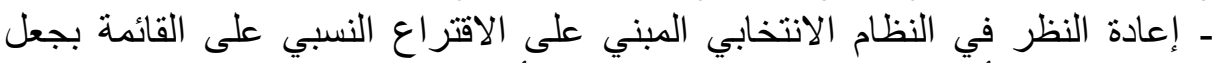

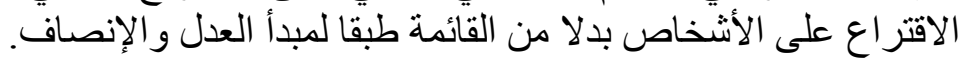

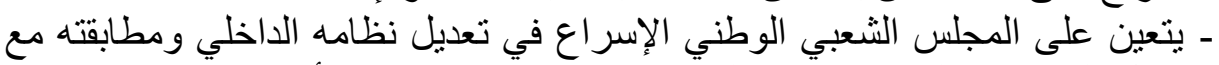

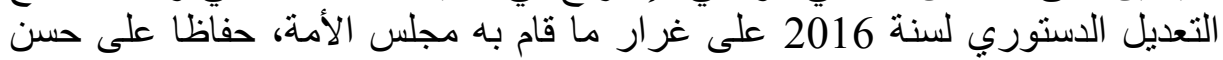

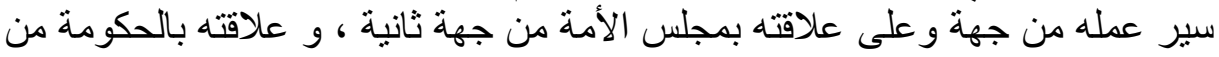
جهة ثالثة - يتعين على النواب وأعضاء مجلس الأمة الاضطلاع بصلاحياتهم في المبادرة

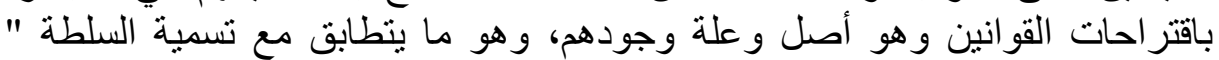




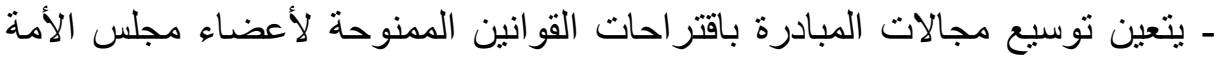

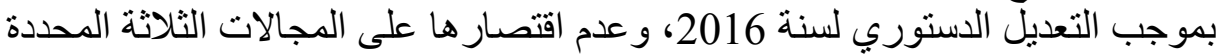

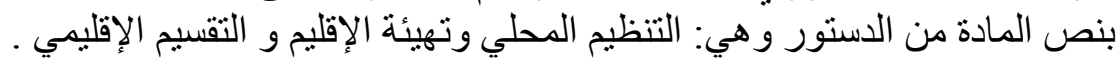

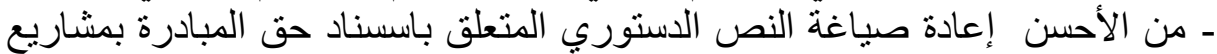

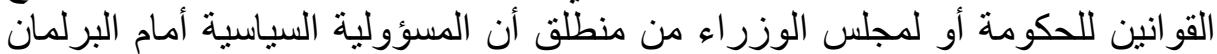

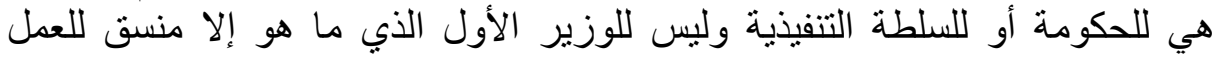
الحكومي.

- يتعين رفع كل القيود أو على الأقل تخفيف حدتها الواقعة على ممارسة أعضاء

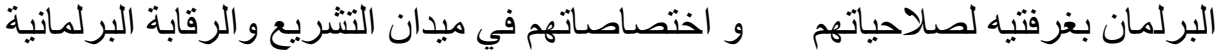

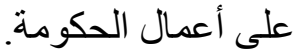

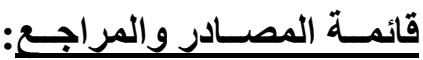

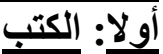

- سعيد بو الثنعير : النظام السياسي الجزائري ، دار الهدى للطباعة و النشر و التوزيع ،

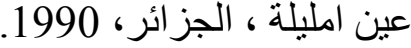

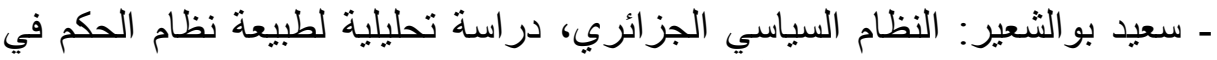

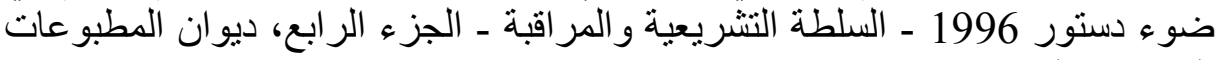

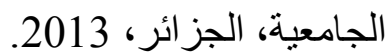

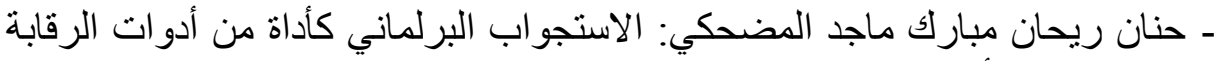

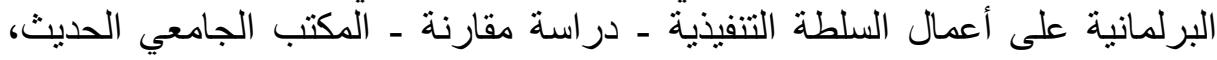

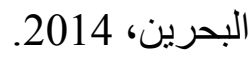

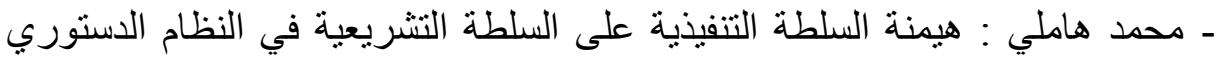

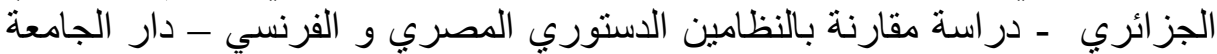

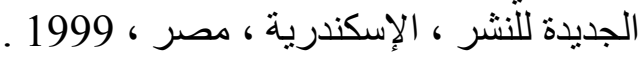

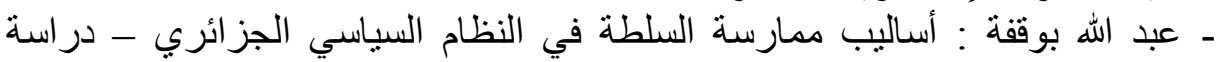

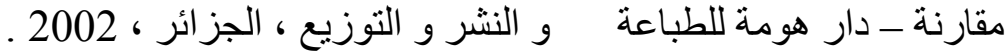

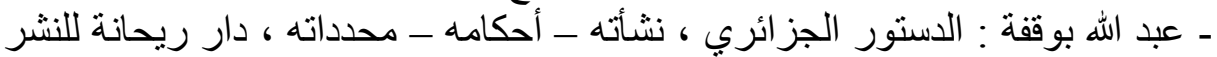

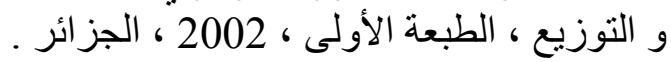

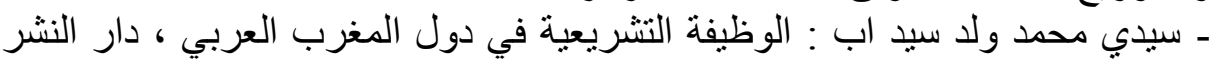

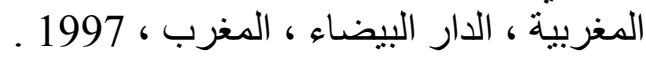
- سعدي محمد الخطيب : العلاقة بين السلطنتين التشريعية و التبنة التفيذية في الأنظمة

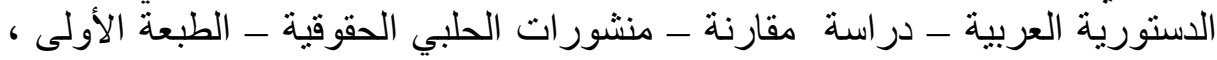

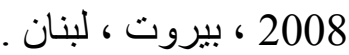
-Maurice Duverger,', Finances publiques', P . U. F, PARIS, 1978 , P 140 - 141

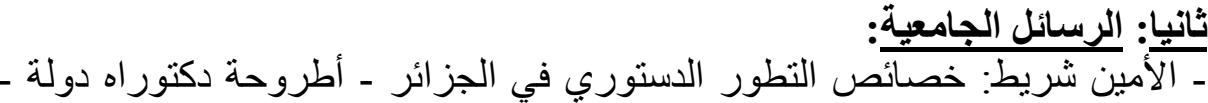
مارس 1991، جامعة قسنطينة، الجز ائر.

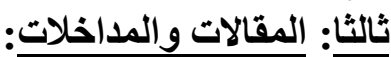

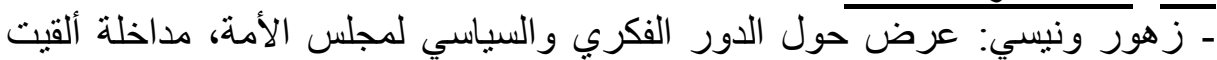

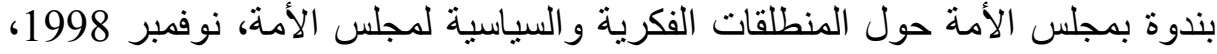

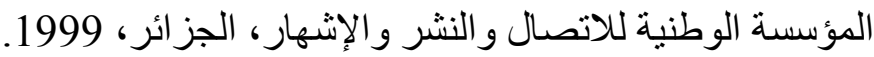

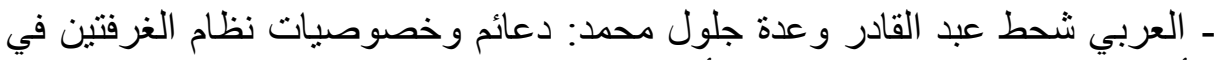

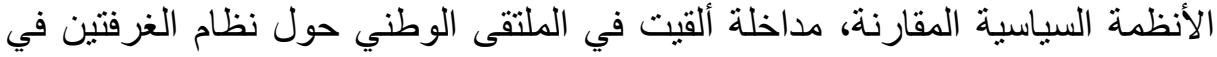


التجربة البرلمانية الجزائرية والأنظمة المقارنة، وزارة العلاقات مع البرلمان، الجزء

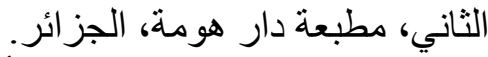
ـ عمار عوابدي مطيدة دور مجلس الأمة في ترسيخ دولة القانون، مداخلة ألقيت في ندوة بمجلس الأمة، نوفمبر 1998 بعنوان: المنطلقات الفكرية والسياسية لمجلس الأمهة، المؤسسة الوطنية للاتصال و النشر والإشهار ، الرويبة، الجزائر الرئ 1999.

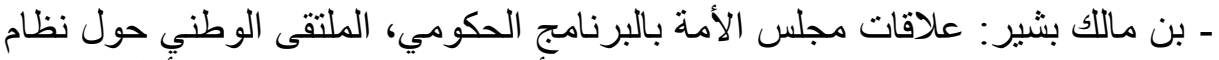

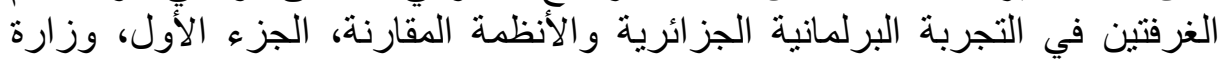

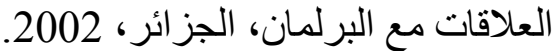

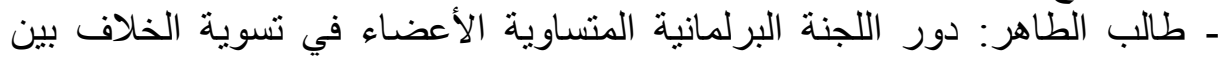

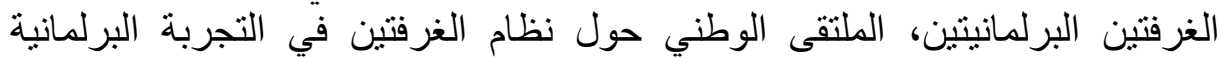

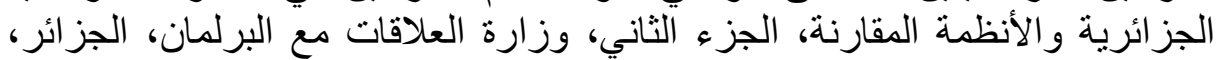
2002

- بولحية إبراهيم: علاقة الحكومة بالبرلمان، وقائع الندوة الوطنية حول العلاقة بين

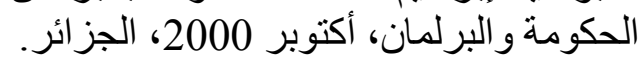
- موسى بودهان: الفصل بين السلطات في النئ النظام القانوني الجزائري، مجلة النائب،

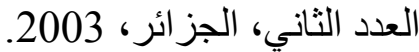

\section{رابعا: النصوص التشريعية: (1}

ـ دستور الجمهورية الجزائرية الديمقر اطية الثعبية لسنة 1963. ـ دستور الجمهورية الجز ائرية الديمقر اطية الثعبية الجية لسنة 1976. ـ دستور الجمهورية الجز ائرية الديمقر اطية الثعبية لائة لسنة 1989. ـ دستور الجمهورية الجز ائرية الديمقر اطية الثنعبية لسنة 1996. ـ دستور الجمهورية الجز ائرية الديمقر اطية النيمر الثعبية لسنة 2016.

2

ـ القانون العضوي رقم 16-10 مؤرخ في 22 ذي القعدة عام 1437 الموافق 25 غشت سنة 2016 يتعلق بنظام الإنتخابات.

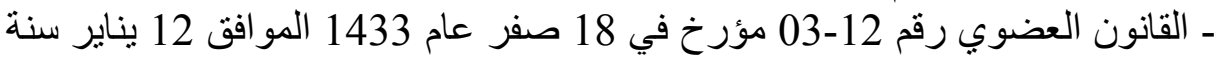

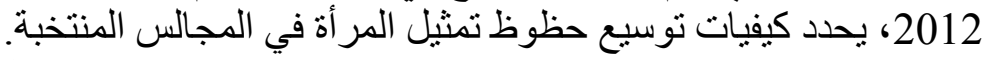

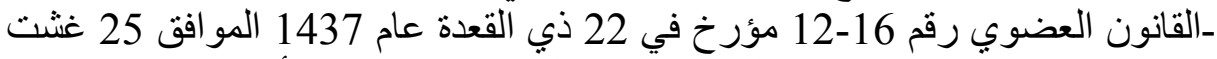

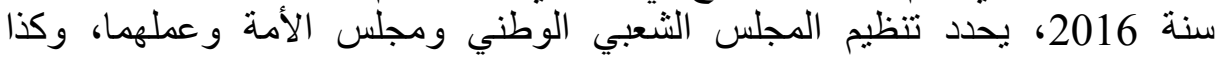

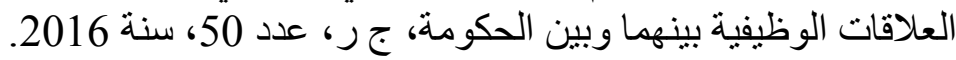




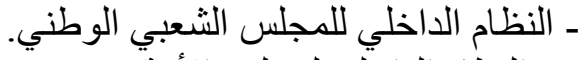

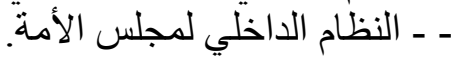

الهوامش:

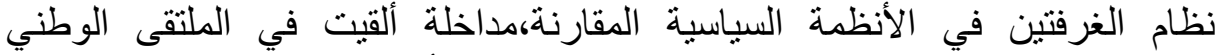
حول:نظام الغرفتين في التجربة البرلمانية الجزائرية والأنظمة المقارنة،هوزارة التية العلاقات

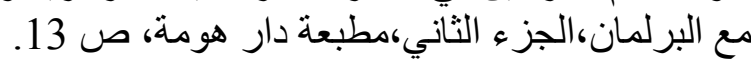
(2)- أنظر : المادة 27 من دستور 1963 و المادة 126 من دستور 1976 من 1976 و المادة 92 من دستور 1989 ـ 198

(3) - راجع الأستاذان العربي شحط عبد القادر و عدة جلول محمد، المرجع السابق،

(4)- طالع:ز هور ونيسي:عرض حول الدور الفكري و السياسي لمجلس الأمة،مداخلة

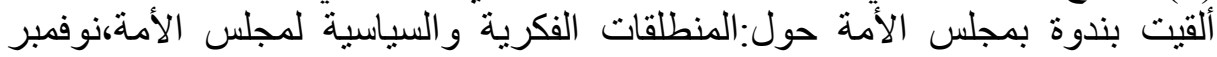

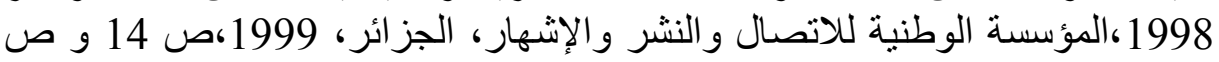

(5)- الأستاذان:العربي شحط عبد القادر وعدة جلول محمد،المرجع السابق، ص 16 و

(6)- نصت المادة 98 من دستور 1996 على أنه:"يمارس السلطة التشريعية برلمان

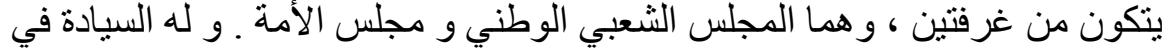

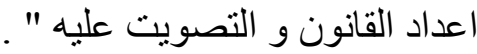

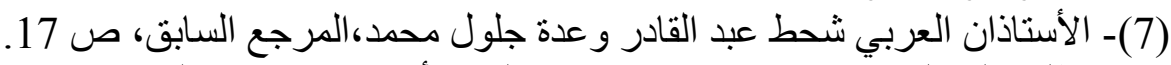

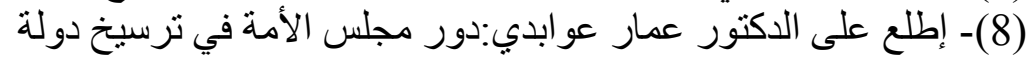

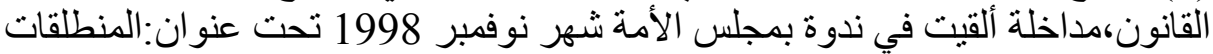

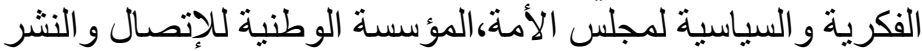

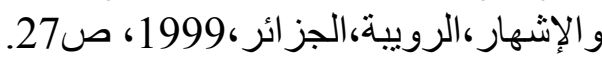

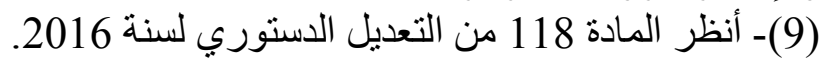

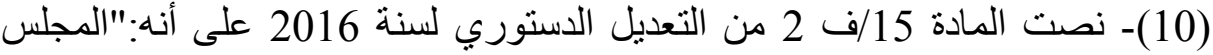

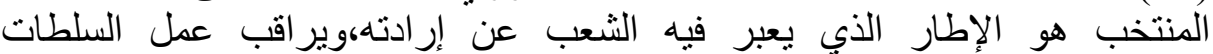

$$
\text { (11)- أنظر المادة 119/ف } 01 \text { من النسادة التعديل الدستوري لسنة } 2016 .
$$

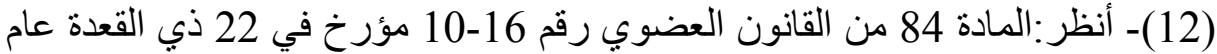
1437 المو افق 25 غشت سنة 25 الفن 2016 يتعلق بنظام الإنتخابات.

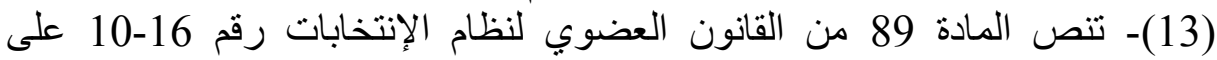

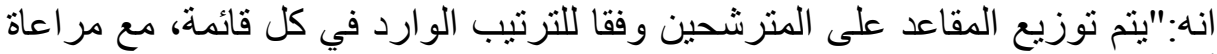

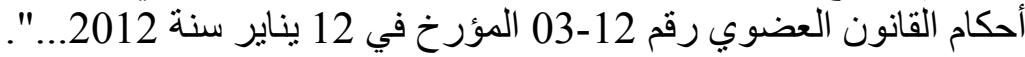

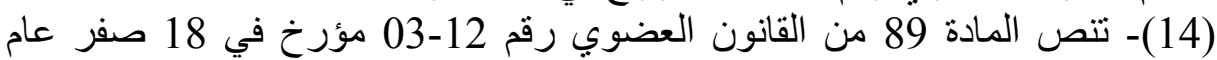

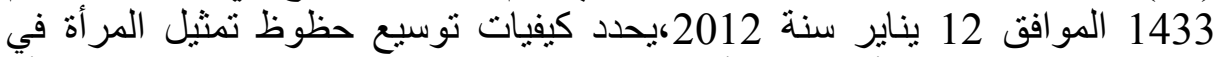

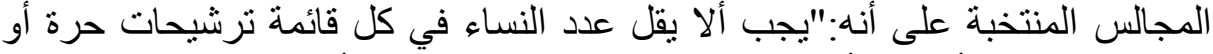

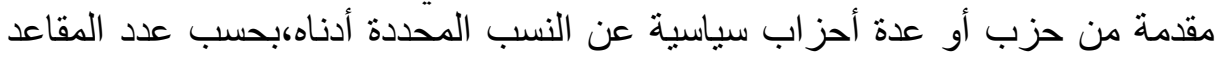

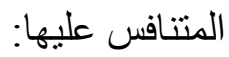
- التخابات المجلس الشعبي الوطني: - 20 20 عندما يكون عدد المقاعد يساوي أربعة (4) مقاعد.

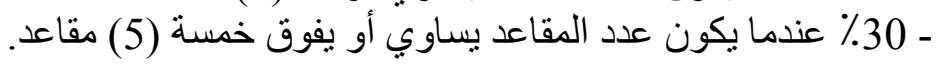


- 35٪ عندما يكون عدد المقاعد يساوي أو يفوق أربعة عثر (14) مقعد. - 40\% عندما يكون عدد المقاعد يساوي أو يفوق إثنين وثثلاثون (32) مقعد. - 50 - 150 بالنسبة لمقاعد الجالية الوطنية في الخارج.

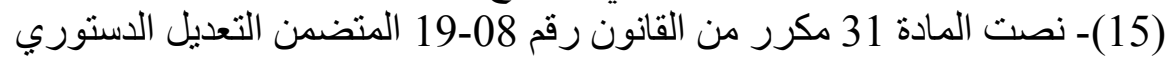

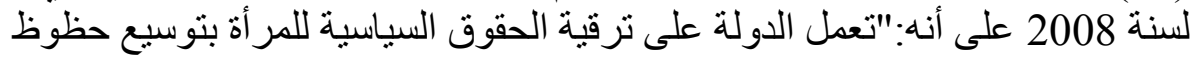

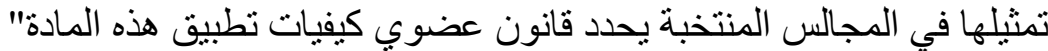

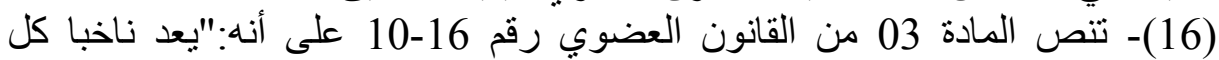

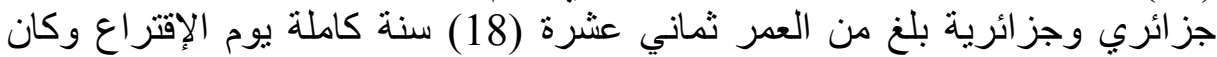
متمتعا بحقوقه المدنية والسياسية، ولم يوجد فئرية في إحدى حالات فقدان الأهلية المحددة في

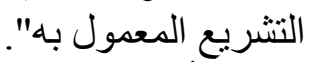

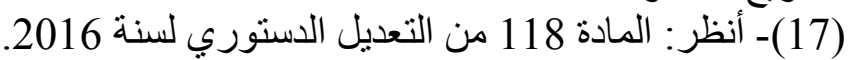

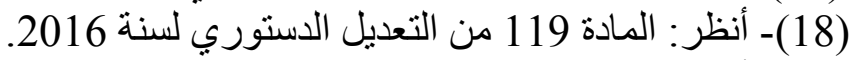

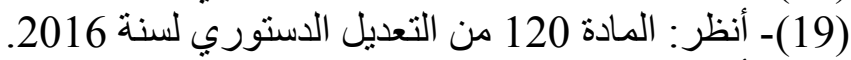

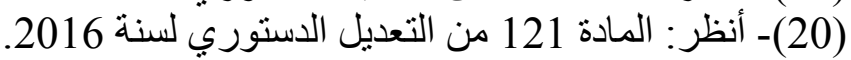

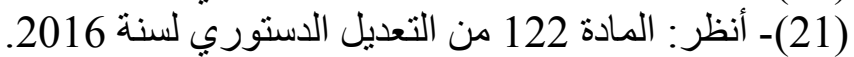

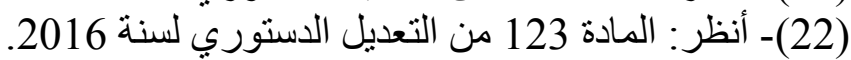

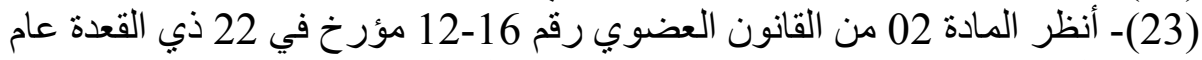

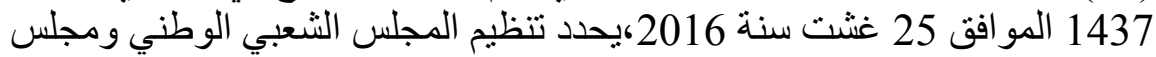

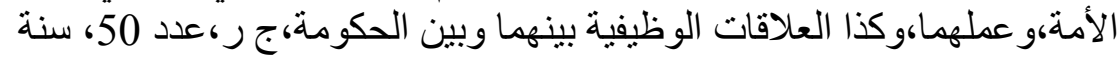

(24)- أنظر المادة 03/ف 12016 من القانون العضوي رقم 16-12-12.

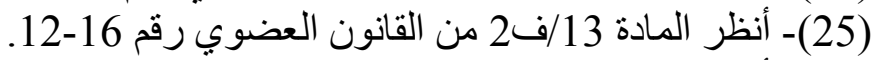

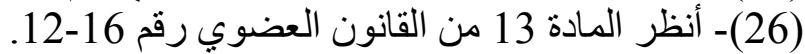

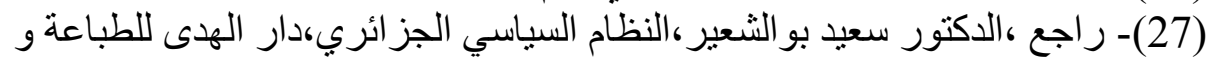

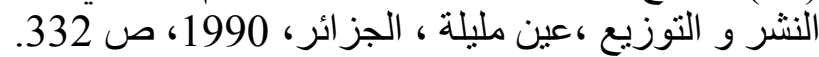

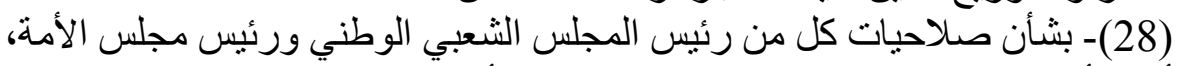

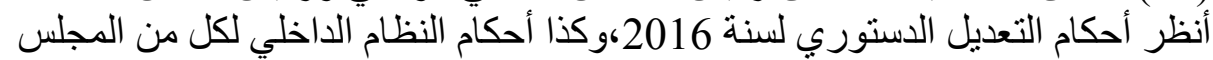
الشعبي الوطني ومجلس الأمةً.

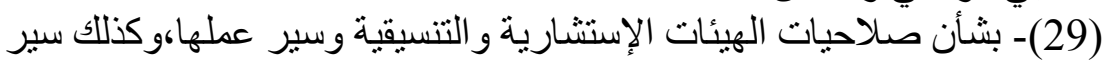

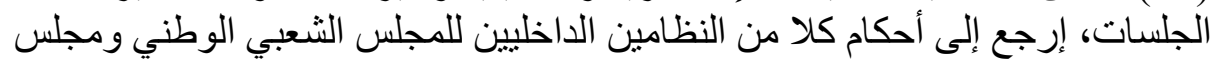

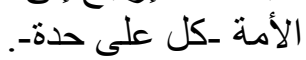

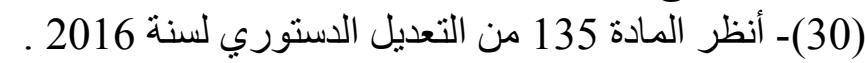

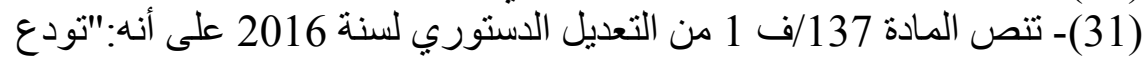

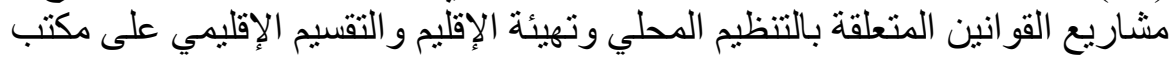

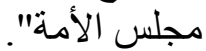
(32)- بالإضافة إلى الميادين التي يخصصها الدستور للبرلمان للتشريع فيها،عددت

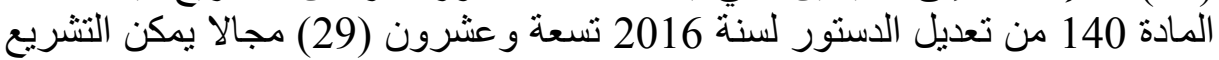

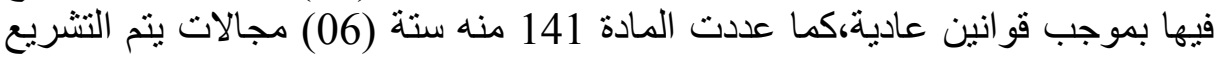
فيها بموجب قو انين عضوينة عانية

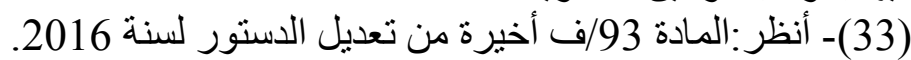

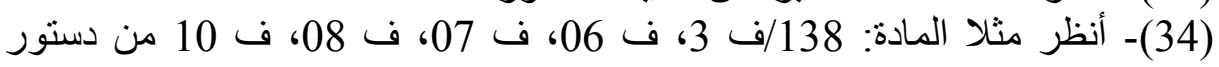


(35)- حول الإجراءات والقيود القانونية الواردة على حق المبادرة باقتراحات القوانين،إرجع إلى أحكام القانون العضوي 16-02 وكذللك إلى كل من النظام الداخلي الإني

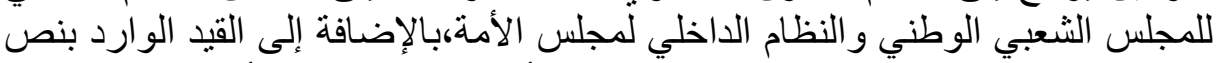

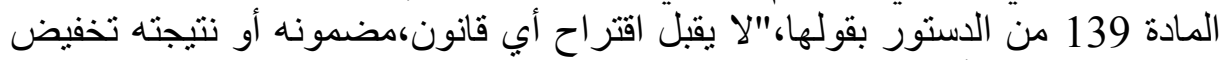

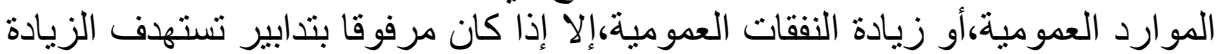

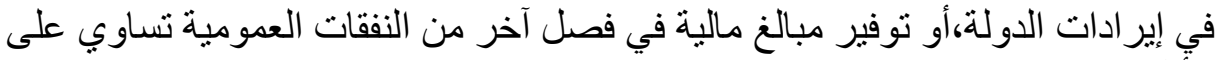

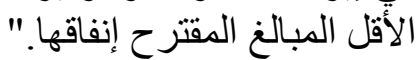

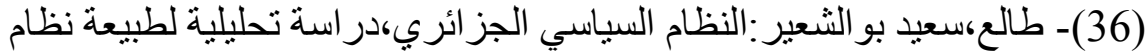

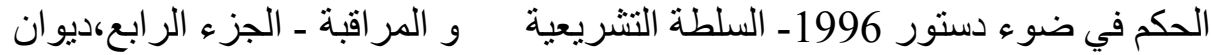

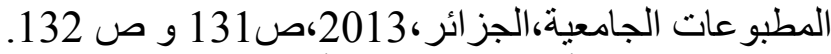

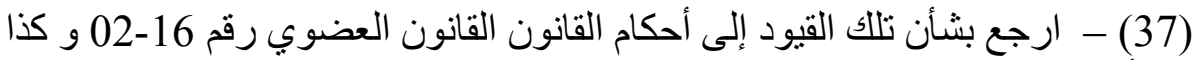

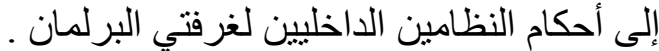

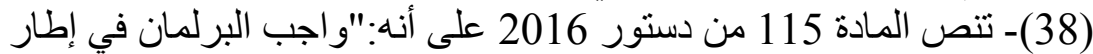

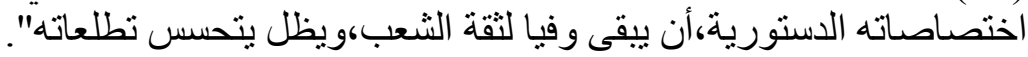

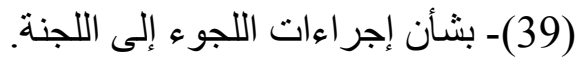

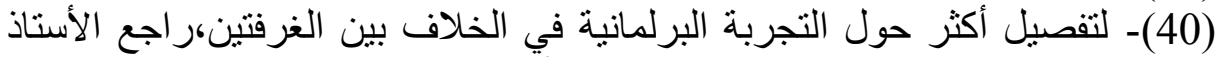

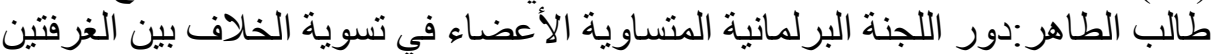

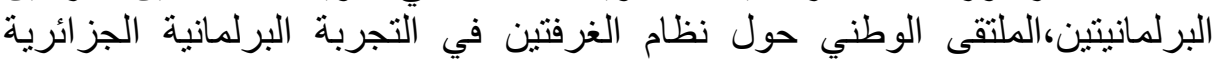
و الأنظمة المقارنة،الجزء الثاني،وزارة العلاقات مع البرلمان،الجزائر،2002 ؛ص 73

$$
\text { (41)- أنظر : المادة } 209 \text { من دستور } 2016 \text { المناد }
$$

(42)- تنص المادة 97 من الدستور على أنه:"ينفذ الوزير الأول وينست مخطط العمل

الذي يصادق عليه المجلس الثعبي الوطني.

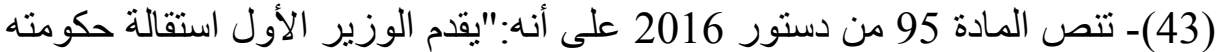

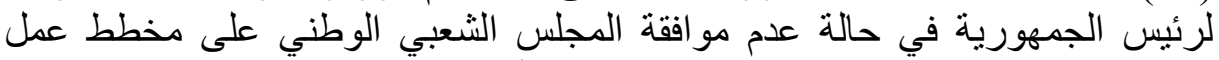

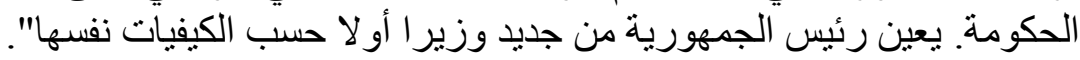

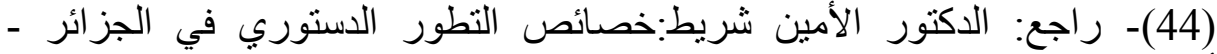

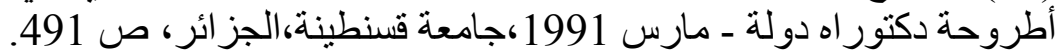

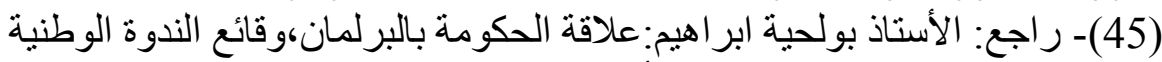

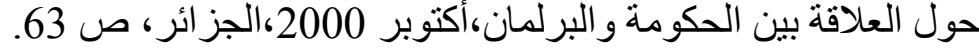

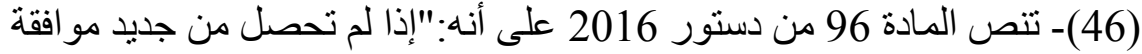

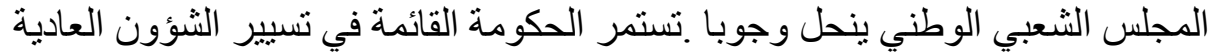

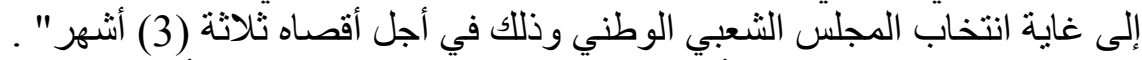

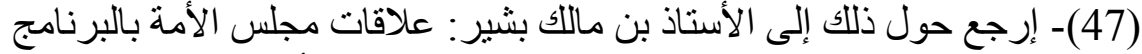

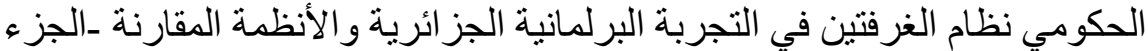

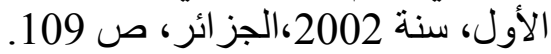

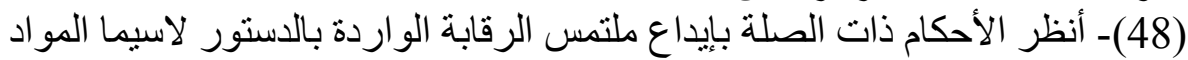

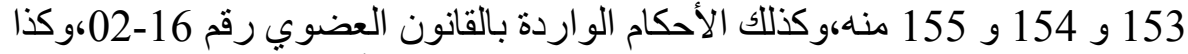
بالنظام الداخلي لكل من المجلس الشعبي الوطني ومجلس الأمة.

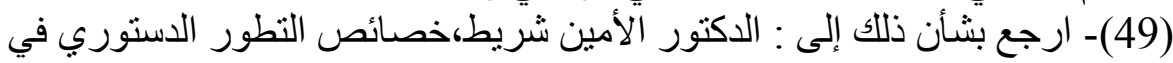

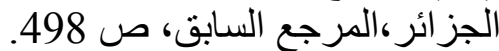

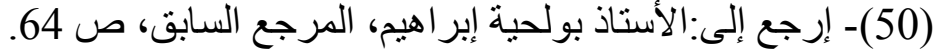

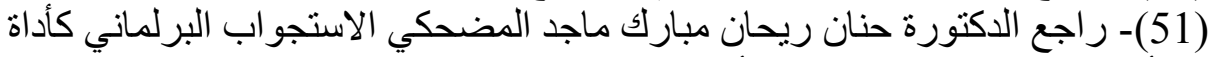

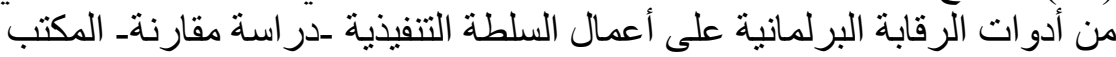

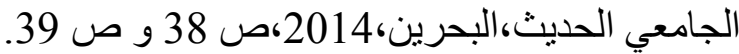


(52)-طالع:الأستاذ موسى بودهان:الفصل بين السلطات في النظام القانوني

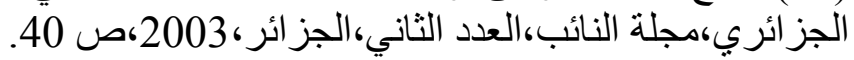

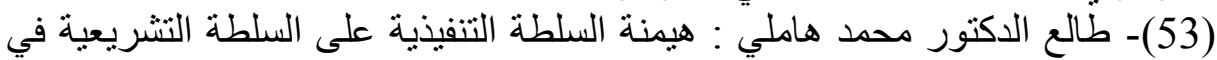

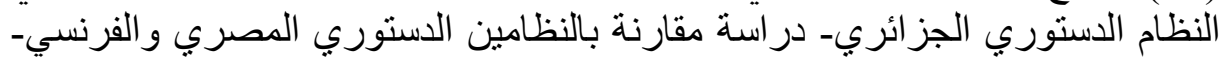

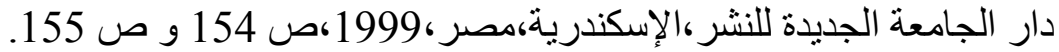

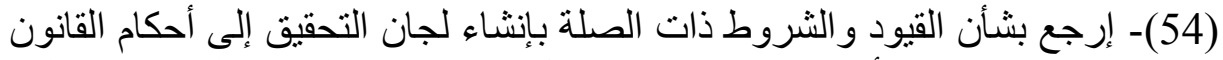

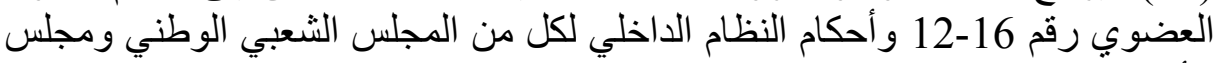

(55)- إطلع على عبد الله بوقفة:أساليب ممارسة السلطة في النظام السياسي الجزائري -

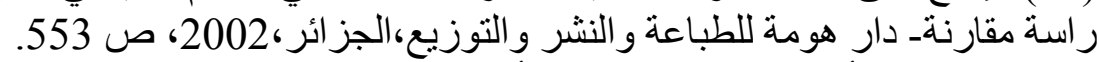

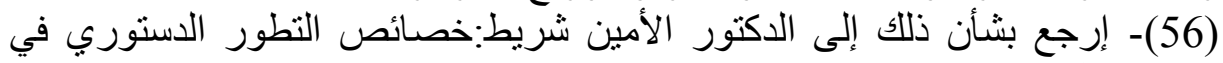

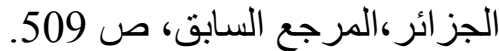
(57)- راجع:الدكتور عبد الله بوقفة :الدستور الجزائري ، نشأتها ـ أحكامه ـ محدداته،دار

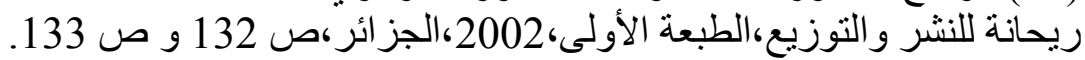

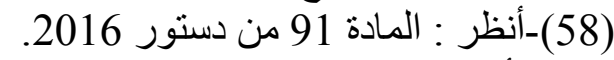

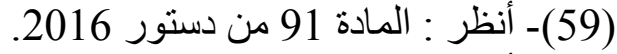

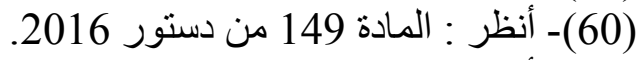

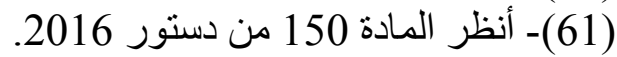

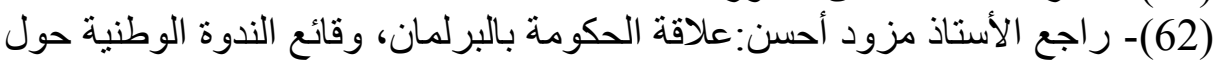

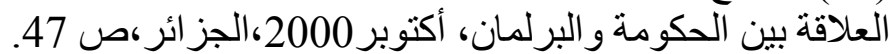

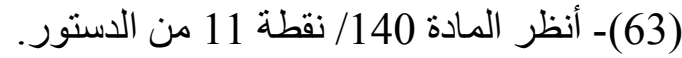

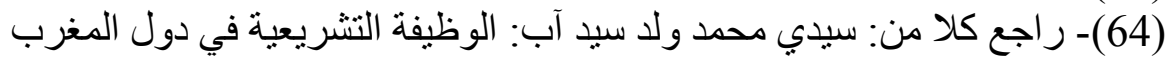

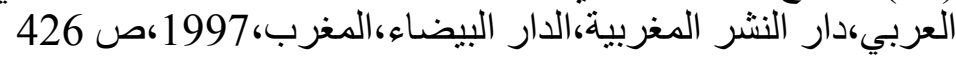
-Maurice Duverger,' Finances publiques', P . U. F, PARIS, 1978 , P 140 - 141.

$$
\text { (65)- أنظر: المادة } 141 \text { من الدستور. }
$$

(66)-ر اجع ـ الدكتورة سعدى محمد الخطيب:العلاقة بين السلطتين التشريعية والتنفيذية في الأنظمة الدستورية العربية ـدراسة مقارنة_منشورات الحلبي الحقوقية، الطبعة الطبة

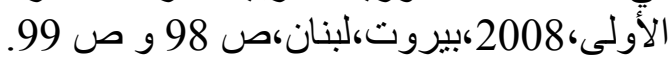

